\title{
A new limestone-dwelling species of Micryletta (Amphibia: Anura: Microhylidae) from northern Vietnam
}

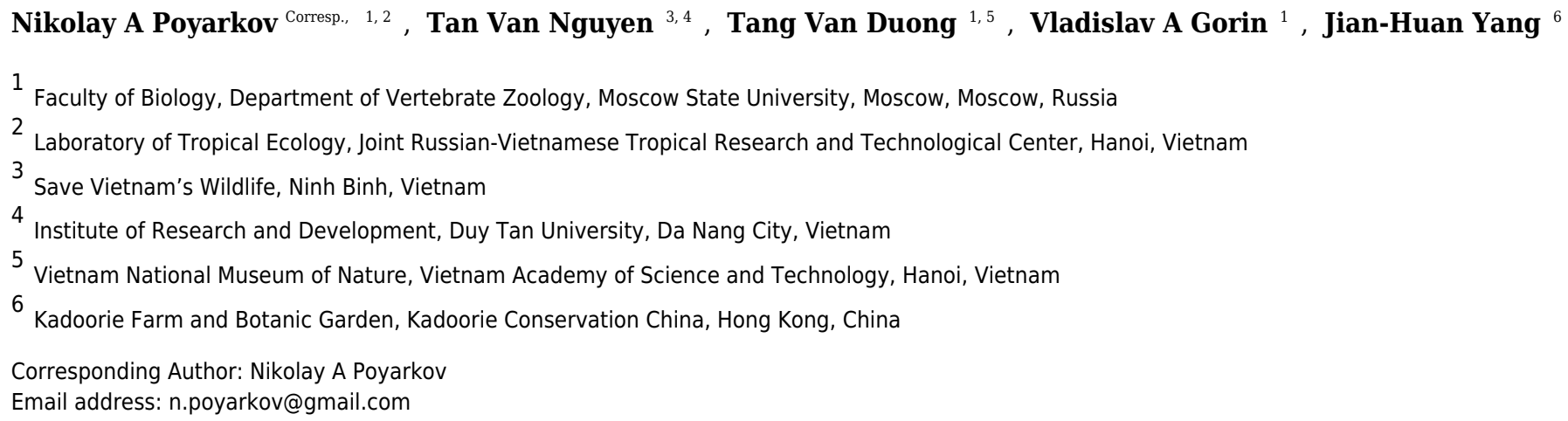

We report on a new species of the genus Micryletta from limestone karst areas in northern Vietnam, which is described on the basis of molecular and morphological evidence. Micryletta nigromaculata sp. nov. is restricted to narrow areas of subtropical forests covering karst massifs in Cat Ba National Park (Hai Phong Province) and Cuc Phuong National Park (Ninh Binh Province) at elevations of 90-150 m a.s.I. In the phylogenetic analyses, the new species is unambiguously positioned as a sister lineage to all remaining species of Micryletta. We also discuss genealogical relationships and taxonomic problems within the genus Micryletta, provide molecular evidence for the validity of $M$. erythropoda and discuss the taxonomic status of $M$. steinegeri. We suggest the new species should be considered as Endangered (Blab(iii), EN) following the IUCN's Red List categories. A discussion on herpetofaunal diversity and conservation in threatened limestone karst massifs in Southeast Asia is provided. 
1 A new limestone-dwelling species of Micryletta (Amphibia: Anura: Microhylidae) from

3

4 5

6

Nikolay A. Poyarkov ${ }^{1,2}$, Tan Van Nguyen ${ }^{3,4}$, Tang Van Duong ${ }^{1,5}$, Vladislav A. Gorin ${ }^{1}$, Jian-

\section{Huan Yang ${ }^{6}$}

1 - Faculty of Biology, Department of Vertebrate Zoology, Moscow State University, Moscow, Moscow, Russia

2 - Laboratory of Tropical Ecology, Joint Russian-Vietnamese Tropical Research and Technological Center, Hanoi, Vietnam

3 - Save Vietnam's Wildlife, Ninh Binh, Vietnam

4 - Institute of Research and Development, Duy Tan University, Da Nang City, Vietnam

5 - Vietnam National Museum of Nature, Vietnam Academy of Science and Technology, Hanoi, Vietnam

6- Kadoorie Farm and Botanic Garden, Kadoorie Conservation China, Hong Kong, China Corresponding author, E-mail: n.poyarkov@gmail.com Abstract. We report on a new species of the genus Micryletta from limestone karst areas in northern Vietnam, which is described on the basis of molecular and morphological evidence. Micryletta nigromaculata sp. nov. is restricted to narrow areas of subtropical forests covering karst massifs in Cat Ba National Park (Hai Phong Province) and Cuc Phuong National Park (Ninh Binh Province) at elevations of 90-150 m a.s.l. In the phylogenetic analyses, the new species is unambiguously positioned as a sister lineage to all remaining species of Micryletta. We also discuss genealogical relationships and taxonomic problems within the genus Micryletta, provide molecular evidence for the validity of $M$. erythropoda and discuss the taxonomic status of M. steinegeri. We suggest the new species should be considered as Endangered (B1ab(iii), EN) following the IUCN's Red List categories. A discussion on herpetofaunal diversity and conservation in threatened limestone karst massifs in Southeast Asia is provided.

\section{INTRODUCTION}


Paddy frogs of the genus Micryletta Dubois, 1987 are a little-known group of microhylids that occurs from southern China, Taiwan, Thailand, Indochina and Myanmar to Nicobar and the Andaman Islands (India), West Malaysia and Sumatra (Indonesia) (Frost, 2018). To date, three species are recognized within the genus: M. inornata (Boulenger, 1890) (type locality: Sumatra, Indonesia; distributed in Sumatra, Nicobar and the Andaman Islands, Peninsular Malaysia, Indochina and southern China), M. steinegeri (Boulenger, 1909) (distributed in southern Taiwan and China) and M. erythropoda (Tarkhnishvili, 1994) (distributed in lowlands of southern Vietnam) (AmphibiaWeb, 2018; Frost, 2018). All these species were initially described within the genus Microhyla Tschudi, 1838; however Dubois (1987) erected a new genus Micryletta, distinguishing it from Microhyla on the basis of a suite of characters including: snout shorter than the eye and eye less prominent (vs. opposite condition in Microhyla); distinct tympanum (vs. hidden in Microhyla); first finger not reduced (vs. opposite condition in some species of Microhyla); digit tips not expanded into disks (vs. expanded in most species of Microhyla); and webbing totally absent in Micryletta (vs. always present in Microhyla) (Dubois, 1987; Bain \& Nguyen, 2004).

Owing to morphological conservativeness, biodiversity of the genus Micryletta is insufficiently studied and its taxonomy was confusing. For instance, M. steinegeri, endemic to Taiwan, was synonymized with $M$. inornata due to the difficulty in distinction between these two species confused with M. inornata (Parker, 1928, 1934; Wang et al., 1989). Morphological study by Dubois (1987) supported the validity of M. steinegeri, which was followed by Fei et al. (2009, 2010) but rejected by Zhao \& Adler (1993), while Matsui \& Busack (1985) confirmed synonymy of Rana gracilipes Gressitt with M. steinegeri. Validity of a subspecies M. inornata lineata (Taylor, 1962) described from southern Thailand was not examined by latter studies. Finally, Microhyla erythropoda Tarkhnishvili, 1994 described from two specimens from southern Vietnam was assigned to the genus Micryletta by Orlov et al. (2002) and Poyarkov et al. (2014), but without providing details on taxonomy of this group.

Works on molecular phylogenetic relationships of the genus Micryletta are scarce. Van der Meijden et al. (2007) as well as Pyron \& Wiens (2011) confirmed the validity of the genus Micryletta and suggested that Micryletta is a sister taxon to the group composed of Microhyla and Glyphoglossus s.lato (including Caluella), though with low values of node support. Matsui et al. (2011) provided an extensive phylogeny of Asian Microhylinae on the basis of 12S rRNA and 
62 16S rRNA mtDNA data, in their tree phylogenetic position of Micryletta within Microhylidae is 63 not supported, though the data suggest paraphyly of $M$. inornata with respect to $M$. steinegeri. 64 The recent phylogenomic work by Peloso et al. (2016) also unambiguously places the genus 65 Micryletta as a sister taxon to the group composed of Microhyla and Glyphoglossus, while a 66 more recent large-scale multilocus phylogeny by $\mathrm{Tu}$ et al. (2018) on the contrary places 67 Micryletta as a sister lineage of the clade joining Uperodon, Phrynella, Metaphrynella and 68 Kaloula. Thus, phylogenetic placement of Micryletta within Microhyinae is still unresolved, and 69 species-level phylogeny of the genus is still absent.

During our recent fieldwork in northern Vietnam, in the limestone forests of Hai Phong

and Ninh Binh provinces we encountered unusual microhylid specimens, which were tentatively identified as Micryletta sp. Consequent phylogenetic analysis of the 16S rRNA mtDNA gene revealed that these populations form a lineage sister to all other recognized species of the genus Micryletta. Closer morphological examination showed that the specimens from Hai Phong and Ninh Binh provinces are clearly distinguished from other known members of Micryletta by a combination of diagnostic morphological features. In the present paper we provide an updated mtDNA-based genealogy of the genus Micryletta and describe a new species from northern Vietnam.

\section{MATERIALS AND METHODS}

Nomenclatural acts. The electronic version of this article in Portable Document Format (PDF) will represent a published work according to the International Commission on Zoological Nomenclature (ICZN), and hence the new names contained in the electronic version are effectively published under that Code from the electronic edition alone (see Articles 8.5-8.6 of the Code). This published work and the nomenclatural acts it contains have been registered in ZooBank, the online registration system for the ICZN. The ZooBank LSIDs (Life Science Identifiers) can be resolved and the associated information can be viewed through any standard web browser by appending the LSID to the prefix http://zoobank.org/. The LSID for this publication is as follows: urn:lsid:zoobank.org:pub:32150A60-5D04-4116-98160ED3E457504A. The online version of this work is archived and available from the following digital repositories: PeerJ, PubMed Central and CLOCKSS. 
92

93

94

95

96

97

Sample collection. Fieldwork was conducted from 10 to 22 October 2013 by Nikolay A. Poyarkov and Jian-Huan Yang in Cat Ba National Park (hereafter - N. P.), Hai Phong Province; and from 8 to 17 June 2017 by Tan Van Nguyen and Tan Nhat La in Cuc Phuong N. P., Ninh Binh Province of northern Vietnam. Surveyed localities are shown in Fig. 1. Geographic coordinates and elevation were obtained using a Garmin GPSMAP 60CSx (USA) and recorded in WGS84 datum. All specimens were preserved in 75\% ethanol, and muscle tissues were preserved in 95\% ethanol for genetic analysis; the holotype specimen was initially fixed in 4\% formalin for 24 hours and later preserved in 75\% ethanol. Specimens and tissues were subsequently deposited in the zoological collections of the Zoological Museum of Lomonosov Moscow State University (ZMMU), Moscow, Russia, the Duy Tan University (DTU), Da Nang Province, Vietnam, and the Museum of Biology, Sun Yat-sen University (SYS), Guangzhou, China. Comparative materials examined are stored in the herpetological collections of ZMMU and in the Zoological Institute of the Russian Academy of Sciences (ZISP) in St. Petersburg, Russia.

Specimens collection protocols and animal use were approved by the animal operations were approved by the Institutional Ethical Committee of Animal Experimentation of Sun Yat-sen University (certificate number 2005DKA21403-JK issued to Ying-Yong Wang and Jian-Huan Yang). Fieldwork, including collection of animals in the field, was authorized by the Department of Forestry, Ministry of Agriculture and Rural Development of Vietnam (permit number 1461/TCLN-BTTN, issued September 23, 2013).

Laboratory methods. For the molecular phylogenetic analyses, we extracted total genomic DNA from ethanol-preserved femoral muscle tissue using standard phenol-chloroformproteinase $\mathrm{K}$ extraction procedures with consequent isopropanol precipitation, for a final concentration of about $1 \mathrm{mg} / \mathrm{ml}$ (protocols followed Hillis et al., 1996 and Sambrook \& David, 2001). We visualized the isolated total genomic DNA in agarose electrophoresis in presence of ethidium bromide. We measured the concentration of total DNA in $1 \mu$ using NanoDrop 2000 (Thermo Scientific), and consequently adjusted to ca. $100 \mathrm{ng} \mathrm{DNA} / \mu \mathrm{L}$.

We amplified mtDNA fragments covering partial sequences 16S rRNA mtDNA gene to obtain a 947 bp-length continuous fragment of mtDNA. 16S rRNA gene was widely applied in biodiversity surveys in amphibians (Vences et al., 2005a, 2005b; Vieites et al., 2009), and has been used in the most of recent phylogenetic studies on Microhylinae (Matsui et al., 2011; 
123 Peloso et al., 2016; Tu et al., 2018). We performed DNA amplification in $20 \mu$ reactions using 124 ca. $50 \mathrm{ng}$ genomic DNA, $10 \mathrm{nmol}$ of each primer, $15 \mathrm{nMol}$ of each dNTP, $50 \mathrm{nMol}$ additional $125 \mathrm{MgCl}_{2}$, Taq PCR buffer (10 mM Tris-HCl, pH 8.3, $50 \mathrm{mM} \mathrm{KCl,} 1.1 \mathrm{mM} \mathrm{MgCl} 2$ and $0.01 \%$ 126 gelatine) and 1 unit of Taq DNA polymerase. Primers used in PCR and sequencing include: L1272188 (AAAGTGGGCCTAAAAGCAGCCA),

128 (CTGACCGTGCAAAGGTAGCGTAATCACT) $16 \mathrm{H}-1$

129 (CTCCGgtCTGAACTCAGAtCACGTAGG) (Matsui et al., 2006; Hedges, 1994). The PCR 130 conditions included an initial denaturation step of $5 \mathrm{~min}$ at $94^{\circ} \mathrm{C}$ and 43 cycles of denaturation 131 for $1 \mathrm{~min}$ at $94^{\circ} \mathrm{C}$, primer annealing for $1 \mathrm{~min}$ with TouchDown program from 65 to $55^{\circ} \mathrm{C}$ 132 reducing $1^{\circ} \mathrm{C}$ every cycle, and extension for $1 \mathrm{~min}$ at $72{ }^{\circ} \mathrm{C}$, and final extension step for $5 \mathrm{~min}$ at $13372^{\circ} \mathrm{C}$.

134 PCR products were loaded onto 1.5\% agarose gels in presence of ethidium bromide and 135 visualized in agarose electrophoresis. When distinct bands were produced, we purified PCR 136 products using $2 \mu \mathrm{l}$ of a 1:4 dilution of ExoSapIt (Amersham) per $5 \mu \mathrm{l}$ of PCR product prior to 137 cycle sequencing. A $10 \mu \mathrm{l}$ sequencing reaction included $2 \mu \mathrm{L}$ of template, $2.5 \mu 1$ of sequencing 138 buffer, $0.8 \mu \mathrm{l}$ of $10 \mathrm{pmol}$ primer, $0.4 \mu \mathrm{l}$ of BigDye Terminator version 3.1 Sequencing Standard 139 (Applied Biosystems) and $4.2 \mu \mathrm{l}$ of water. The cyclesequencing used 35 cycles of $10 \mathrm{sec}$ at $96^{\circ} \mathrm{C}$, $14010 \mathrm{~s}$ at $50^{\circ} \mathrm{C}$ and $4 \mathrm{~min}$ at $60^{\circ} \mathrm{C}$. We purified the cyclesequencing products by ethanol 141 precipitation. We carried out sequence data collection and visualization on an ABI 3730xl 142 Automated Sequencer (Applied Biosystems). The obtained sequences are deposited in GenBank 143 under the accession numbers MH756146-MH756156 and MH879840-MH879845 144 (Supplementary Table S1).

145 Phylogenetic analyses. To reconstruct the matrilineal genealogy, we used all 16S rRNA 146 sequences for Micryletta available in GenBank and our newly obtained sequences of Micryletta 147 sp. and sympatric popualtions of Micryletta cf. inornata (see Supplementary Table S1). We also 148 added sequences of representatives of all currently recognized Microhylinae genera and a 149 sequence of Chaperina fusca (Chaperininae). In total, we obtained data for 16S rRNA for 43 150 specimens, which included six sequences of Micryletta sp. from Cat Ba Island, three sequences 151 of Micryletta sp. from Cuc Phuong N. P., three sequences of Micryletta cf. inornata from Cat Ba 152 Island, three sequences of Micryletta cf. inornata from Cuc Phuong N.P., 11 sequences of all 153 other species of Micryletta from Thailand, Laos, Vietnam and Taiwan, including topotype 
154 specimens of M. erythropoda (Ma Da, Dong Nai, Vietnam) and M. steinegeri (Taiwan), 16 155 outgroup sequences of other Microhylinae representatives and of Chaperina fusca, and a 156 sequence of Kalophrynus interlineatus (Blyth) (Kalophryninae), which was used to root the tree 157 (data summarized in Supplementary Table S1).

158 We initially aligned nucleotide sequences using ClustalX 1.81 (Thompson et al., 1997) 159 with default parameters, and then optimized them manually in BioEdit 7.0.5.2 (Hall, 1999) and 160 MEGA 6.0 (Tamura et al., 2013). We used MODELTEST v.3.06 (Posada \& Crandall, 1998) to 161 estimate the optimal evolutionary models to be used for the data set analysis. The best-fitting 162 model for the 16S rRNA gene fragment was the GTR+G model of DNA evolution as suggested by the Akaike Information Criterion (AIC). We determined mean uncorrected genetic distances (p-distances) between sequences with MEGA 6.0.

We inferred the matrilineal genealogy using Bayesian inference (BI) and Maximum Likelihood (ML) approaches. We conducted BI in MrBayes 3.1.2 (Ronquist \& Huelsenbeck, 2003); Metropolis-coupled Markov chain Monte Carlo (MCMCMC) analyses were run with one cold chain and three heated chains for one million generations and sampled every 100 generations. We performed five independent MCMCMC runs and the initial 2,500 trees were discarded as burn-in. We assessed confidence in tree topology by the frequency of nodal resolution (posterior probability; BI PP) (Huelsenbeck \& Ronquist, 2001). We conducted ML analyses using the RAxML web server (http://embnet.vital-it.ch/raxml-bb/, Stamatakis et al., 2008); it was used to search ML trees using the gamma model of rate heterogeneity option. We assessed nodal confidence by non-parametric bootstrapping (ML BS) with 1000 pseudoreplicates (Felsenstein, 1985).

In both datasets, we regarded tree nodes with ML BS values $75 \%$ or greater and BI PP values over 0.95 to be sufficiently resolved a priori. ML BS values between $75 \%$ and $50 \%$ and BI PP values between 0.95 and 0.90 were regarded as tendencies. Lower values were considered to indicate unresolved nodes (Huelsenbeck \& Hillis, 1993).

Morphological description. Specimens of Micryletta sp. were photographed in life and after preservation; specimens were euthanized by $20 \%$ solution of benzocaine. Measurements were taken using a digital caliper under a light dissecting microscope to the nearest $0.01 \mathrm{~mm}$, subsequently rounded to $0.1 \mathrm{~mm}$. The morphometrics of adults and character terminology follow Poyarkov et al. (2014): (1) snout-vent length (SVL; measured from the tip of the snout to 
185 cloaca); (2) head length (HL; measured from the tip of snout to hind border of jaw angle); (3) 186 snout length (SL; measured from the anterior corner of eye to the tip of snout); (4) eye length 187 (EL; measured as the distance between anterior and posterior corners of the eye); (5) nostril-eye 188 length (N-EL; measured as the distance between the anterior corner of the eye and the nostril 189 center); (6) head width (HW; measured as the maximum width of head on the level of mouth 190 angles in ventral view); (7) internarial distance (IND; measured as the distance between the 191 central points of nostrils); (8) interorbital distance (IOD; measured as the shortest distance 192 between the medial edges of eyeballs in dorsal view); (9) upper eyelid width (UEW; measured as 193 the maximum distance between the medial edge of eyeball and the lateral edge of upper eyelid); 194 (10) Tympanum length, measured as the horizontal tympanum diameter (TMP); (11) forelimb 195 length (FLL; measured as the length of straightened forelimb to the tip of third finger); (12) 196 lower arm and hand length (LAL; measured as the distance between elbow and the tip of third 197 finger); (13) hand length (HAL; measured as the distance between the proximal end of outer 198 palmar (metacarpal) tubercle and the tip of third finger); (14) first finger length (1FL, measured 199 as the distance between the tip and the distal end of inner palmar tubercle); (15) inner palmar 200 tubercle length (IPTL; measured as the maximum distance between proximal and distal ends of 201 inner palmar tubercle); (16) outer palmar tubercle length (OPTL; measured as the maximum 202 diameter of outer palmar tubercle); (17) third finger disk diameter (3FDD); (18) hindlimb length 203 (HLL; measured as the length of straightened hindlimb from groin to the tip of fourth toe); (19) 204 tibia length (TL; measured as the distance between the knee and tibiotarsal articulation); (20) 205 foot length (FL; measured as the distance between the distal end of tibia and the tip of fourth 206 toe); (21) inner metatarsal tubercle length (IMTL; measured as the maximum length of inner 207 metatarsal tubercle); (22) first toe length (1TOEL), measured as the distance between the distal 208 end of inner metatarsal tubercle and the tip of first toe; (23) fourth toe disk diameter (4TDD). 209 Additionally for holotype description we took the following measurements: (24-26) second to 210 fourth finger lengths (2-3FL-O, 4FL-I; for outer side $(\mathrm{O})$ of the second and third, inner side (I) 211 of the fourth, measured as the distance between the tip and the junction of the neighboring 212 finger); (27-30) second to fifth toe lengths (measured as the outer lengths for toes II-IV, as the 213 inner length for toe V; 2-5TOEL); (31) nostril-snout length (N-SN), measured as the distance 214 between the middle of nostril and snout tip. Terminology for describing eye coloration in living 215 individuals is in accordance with Glaw \& Vences (1997); subarticular tubercle formulas follow 
216 those of Savage (1975). All measurements were taken on the right side of the examined

217 specimen. Sex was determined by gonadal inspection following dissection.

218 We compared morphological characters of the new species with other members of the

219 genus and comparative data obtained from the literature: Micryletta inornata (Boulenger)

220 (Boulenger, 1890; Taylor, 1962; Bain \& Nguyen, 2004); M. steinegeri Boulenger (Boulenger,

221 1909; Wang et al., 1989; Fei et al., 2009, 2010), and M. erythropoda (Tarkhnishvili)

222 (Tarkhnishvili, 1994).

223 For preparing maps free SRTM (Shuttle Radar Topography Mission) Digital Elevation

224 Datasets (accessed from ftp://e0srp01u.ecs.nasa.gov/srtm) and free country level GIS data

225 downloaded from DIVA-GIS portal (http://www.diva-gis.org/gdata) were processed using the

226 Global Mapper v. 10.0 software (Global Mapper LLC, 2009).

227

228

229

\section{RESULTS}

Phylogenetic relationships. In the final alignment of 16S rRNA gene, of 947 sites 554 were conserved and 346 sites were variable, of which 250 were found to be parsimonyinformative. The transition-transversion bias (R) was estimated as 2.62. Nucleotide frequencies were $\mathrm{A}=33.81 \%, \mathrm{~T}=23.23 \%, \mathrm{C}=23.88 \%$, and $\mathrm{G}=19.04 \%$ (data for ingroup only).

The studied 16S rRNA fragment was unable to fully resolve the genealogical relationships within Microhylinae (see Fig. 2). The genus Micryletta is suggested as a sister lineage to the clade joining Kaloula, Phrynella, Metaphrynella and Uperodon, though with moderate levels of node support (0.94/78, hereafter node support values are given for BI PP/ML $\mathrm{BS}$, respectively). According to the results of phylogenetic analyses, the newly discovered populations of Micryletta sp. from northern Vietnam form a well-supported clade (1.0/100) markedly distinct from all other examined Microhylinae representatives. The Micryletta sp. clade is reconstructed as a sister lineage to all other Micryletta specimens (1.0/97), the latter also forming a clade (1.0/95) (Fig. 2). Genealogical relationships within this group suggest that specimens from the type locality of M. erythropoda (Ma Da Nature Reserve, Dong Nai Province, Vietnam) are clustered with a sample of Micryletta sp. from Ranong Province, Thailand $(1.0 / 100)$ (the latter sample was previously assigned to M. inornata lineata in Matsui et al., 2011). This clade is a sister lineage to the group joining all remaining specimens of Micryletta inornata and M. steinegeri. Evolutionary relationships within the latter group are essentially 
247

248

249

250

251

252

253

254

255

256

257

258

259

260

261

262

263

264

265

266

267

268

269

270

271

272

273

274

275

276

unresolved with the Taiwanese population of $M$. steinegeri being nested within the radiation of mainland populations of $M$. inornata (see Fig. 2). Populations of $M$. cf. inornata sympatric with the new species in Cat Ba and Cuc Phuong national parks form a weakly supported clade ( $M$. cf. inornata $\mathrm{B} ; 0.77 / 91)$.

Sequence variation. The uncorrected $p$-distances for the $16 \mathrm{~S}$ rRNA gene fragment are shown in the Table 1. The interspecific distances within Micryletta varied from $p=1.4 \%$ (between $M$. steinegeri and $M$. cf. inornata B) to $p=7.7 \%$ (between $M$. erythropoda and Micryletta sp. from northern Vietnam). Intraspecific distances ranged from $p=0.7 \%$ in Micryletta sp. from northern Vietnam (divergence between $\mathrm{Cat} \mathrm{Ba}$ and Cuc Phuong populations) to $p=2.2 \%$ in $M$. inornata (but only $p=1.3 \%$ upon the exclusion of a notably divergent KUHE 35133 sample from Laos, see Table 1). The newly discovered population of Micryletta sp. was clearly divergent from all other known species of Micryletta and other examined microhylids.

\section{TAXONOMIC ACCOUNT}

The newly-discovered populations of microhylids from $\mathrm{Cat} \mathrm{Ba}$ and $\mathrm{Cuc}$ Phuong are clustered with the genus Micryletta, forming a divergent lineage sister to all other representatives of the genus examined. Due to both morphological (see below) and molecular differences of the newly-collected specimens to all currently recognized species in the genus, herein we describe it as a new species of Micryletta.

\section{Micryletta nigromaculata sp. nov.}

(Figs. 3-6; Table 2)

Holotype. ZMMU A5934, adult male (field ID NAP-06531), collected by Nikolay A. Poyarkov on 15 October 2013 from the limestone evergreen forest $\left(20.8123^{\circ} \mathrm{N}, 106.9988^{\circ} \mathrm{E}\right.$, at an elevation of 90 m a.s.1.), Cat Ba National Park, Hai Phong Province, northern Vietnam.

Paratypes. ZMMU A5935-A5948 (14 adult males, field IDs NAP-03343-03348; NAP03576-03579; NAP-03589-03590; NAP-08445-08446), with collection information same as for the holotype; SYS a007400 (field ID NAP-08444), adult male with collection information same as for the holotype. 

303-305 (three gravid females, field IDs CP.2018.19, CP.2018.20, CP.2018.52) collected by Tan Van Nguyen and Tan Nhat La on 3 June 2018 in the secondary forest on limestone $\left(20.2594^{\circ} \mathrm{N}\right.$, $105.6928^{\circ}$ E, at elevation of $150 \mathrm{~m}$ a.s.1.), Cuc Phuong National Park, Ninh Binh Province, northern Vietnam.

Diagnosis. The new species is assigned to the genus Micryletta by the following combination of morphological features: small body size; vomerine teeth absent; tympanum small, rounded, externally visible; very prominent subarticular tubercles on fingers and toes; three well-developed metacarpal tubercles; distinct supernumerary palmar and metatarsal tubercles posterior to base of digits; first finger not reduced; digit tips expanded to very small disks and webbing on fingers and toes totally absent (Dubois, 1987; Fei et al., 2009). Micryletta nigromaculata sp. nov. is distinguished from all of its congeners by a combination of the following morphological characters: body size small (SVL 18.5-23.0 mm in males, 24.2-25.9 $\mathrm{mm}$ in females); body habitus moderately slender; head wider than long; snout obtusely rounded in profile; eye length equal to or shorter than snout length; interorbital distance two times wider than upper eyelid width; tibiotarsal articulation of adpressed limb reaching the level of eye center; dorsal surface slightly granular with small round flattened tubercles; supratympanic fold present, thick, glandular; outer metatarsal tubercle absent; dorsum coloration brown to reddishbrown; dorsum with dark-brown irregular hourglass-shaped pattern edged with orange; body flanks brown with dark-brown to black patches or spots edged with white, a large black blotch in inguinal area on each side; lateral sides of head immaculate reddish brown lacking white patches; venter whitish with indistinct grey pattern; and throat in males whitish with light-grey marbling.

Description of holotype: Adult male, small-sized specimen in a good state of preservation; body habitus moderately slender, body elongated oval-shaped (Figs. 3, 4); head wider than long (HL/HW ratio 84.4\%); snout short (SL/SVL ratio 12.1\%), rounded in dorsal view (Fig. 3A) and bluntly rounded in profile, slightly projecting beyond lower jaw (Fig. 3C); eyes comparatively large (EL/SVL ratio 12.6\%), slightly protuberant in dorsal and lateral views, slightly longer than snout (EL/SL 104.0\%) and shorter than the interorbital distance (EL/IOD 86.4\%). Top of head flat; canthus rostralis distinct, rounded; loreal region almost vertical, noticeably concave; nostril round, lateral, located closer to the tip of snout than to eye (N-EL/SVL ratio $8.5 \%$; N-SN/ N-EL ratio 79.0\%) (Fig. 3C); interorbital distance wider than internarial distance (IND/IOD ratio 
308

309

310

311

312

313

314

315

316

317

318

319

320

321

322

323

324

325

326

327

328

329

330

331

332

333

334

335

336

337

338

66.7\%), about two times wider than upper eyelid (UEW/IOD ratio 54.5\%). Pineal spot absent; tympanum small (TYD/SVL ratio 5.1\%), round, relatively indistinct with tympanic rim not elevated above the tympanal area; supratympanic fold thick, rounded, glandular, gently curving from posterior corner of eye towards axilla. Choanae elongated and oval-shaped, widely spaced; upper jaw edentate; vomerine teeth absent; tongue without papillae, roundly spatulate, lacking posterior notch and free behind for $3 / 4$ of its length.

Forelimbs short and slender (FLL/SVL ratio 72.0\%); lower arm comparatively long and slender (LAL/SVL ratio 54.1\%), hand less than half the length of the forelimb (HAL/FLL ratio 42.7\%). Fingers slender (Fig. 3D; Fig. 5A), completely free of webbing, slightly dorso-ventrally flattened, lacking lateral skin fringes; the first finger well-developed, slightly shorter than the second finger (1FL/2FL ratio 74.8\%); relative finger lengths: $\mathrm{I}<\mathrm{IV}<\mathrm{II}<\mathrm{III}$; tips of all finger rounded, not expanded to disks; subarticular tubercles on fingers rounded and very prominent, subarticular tubercle formula: 1, 1, 2, 2; nuptial pad absent; three palmar (metacarpal) tubercles: inner metacarpal tubercle distinct, rounded and flat (IPTL/SVL ratio 2.4\%); outer metacarpal tubercle elongated, reniform, located on the outer proximal edge of the palm (OPTL/SVL ratio $3.3 \%$ ); medial metacarpal tubercle large, rounded and prominent, twice the diameter of the inner metacarpal tubercle, located closer to the outer metacarpal tubercle; three rounded and prominent supernumerary palmar tubercles each at the base of fingers II-IV about the same size as inner metacarpal tubercle, a small rounded supernumerary palmar tubercle between medial metacarpal tubercle and the tubercle at the base of finger III, much smaller than metacarpal tubercles.

Hindlimbs slender and comparatively long (HLL/SVL ratio 152.9\%), more than two times the length of the forelimb (FLL/HLL 47.1\%); tibia long and slender (TL/SVL 51.4\%), around one-third of hindlimb length (TL/HLL 33.6\%); heels meet when hindlimbs located at right angles to the body, tibiotarsal articulation of adpressed limb reaching the level of eye center; foot slightly longer than tibia length (FL/TL 105.3\%). Relative toe lengths: $\mathrm{I}<\mathrm{V}<\mathrm{II}<\mathrm{III}<\mathrm{IV}$; tarsus smooth, inner tarsal fold absent; tips of all toes rounded, weakly dilated into small disks, slightly wider than those of fingers (3FDD/4TDD ratio 76.1\%); toes completely free of webbing (Fig. 3E; Fig. 5B); subarticular tubercles on toes round and prominent, subarticular tubercle formula: 1, 1, 2, 3, 2; metatarsal tubercle single: inner metatarsal tubercle oval-shaped, prominent, much shorter than the half of first toe (IMTL/1TOEL ratio 36.8\%); outer metatarsal and supernumerary metatarsal tubercles absent. 

small round low tubercles and granules evenly scattered being more prominent in the posterior part of dorsum, dorsal surfaces of forelimbs smooth, dorsal surfaces of hindlimbs covered by

342 irregularly scattered flat tubercles and pustules; flanks of body and lateral sides of head smooth, with small granules present only in axillary region; upper eyelid without superciliary spines; supratympanic fold thick and glandular; ventral side of body and limbs smooth. Cloacal opening unmodified, directed posteriorly, at upper level of thighs.

Coloration in life: Dorsum coloration in life reddish-brown (Fig. 3A, Fig. 4); dorsal surfaces of forelimbs light brownish-orange on upper arms, reddish-brown on lower arms, dorsal surfaces of hindlimbs slightly darker and tan-brownish to caramel-brown in coloration; dorsal surfaces with distinct dark pattern: forehead and snout lighter; an distinct light-brownish interorbital bar runs transversally across the head between the medial parts of upper eyelids; interorbital bar forms a very distinct broad V-shaped figure across the head running posteriorly forming irregular hourglass-shaped dark-brown pattern; two smaller blotches in scapular region; dark pattern on dorsum edged with thin light-brown to orange line; head laterally dark red-brown, supratympanic fold black ventrally, edged with light cream-beige thin line dorsally, which continues to upper eyelid and canthus rostralis (Fig. 4); flanks with white speckling and characteristic large black patches edged with thin white lines; larger black blotches located at axillary and groin areas, the latter reaching the sacral area; fingers and toes dorsally beige with indistinct brownish mottling, venter whitish, with indistinct light grey marbled pattern on throat and chest (Fig. 3B); iris dark brown with golden speckles in the upper and lower thirds.

Coloration in preservative: After preservation in formalin and storage in ethanol, the general coloration pattern did not fade, dorsal coloration changed to darker greyish-brown, ventral surface of chest, belly, limbs turned whitish-beige; dorsal pattern, dark spots on flanks not changed, dark brown pattern changed to lighter brown; iris coloration faded and turned completely dark.

Measurements of holotype (all in $\mathrm{mm}$ ): For comparative measurements see Table 2. Additional measurements: 2FL 2.7; 3FL 4.3; 4FL 2.4; 2TOEL 3.3; 3TOEL 5.0; 4TOEL 6.9; 5TOEL 3.1; N-SN 1.5.

Variation and sexual dimorphism. Individuals of the type series and the referred materials are generally quite similar in appearance and agree well with description of holotype, 
370 but show certain variation in coloration (Fig. 6). Dorsal color may vary from bright reddish-

371 brown (Fig. 6A, B) to ochre-brown and light brown (Fig. 6C) and purplish brown (Fig. 6D).

372 Dorsal pattern is very variable, in some specimens forming irregular confluent blotches,

373 hourglass-shapes or "teddy-bear"-like shapes, see Rakotoarison et al. (2017) for definition, but

374 are always edged with lighter (beige or orange) color. Size and position of black blotches on

375 flanks also varies a lot, dark spots in sacral area may be connected (Fig. 4; Fig. 6C) or

376 disconnected (Fig. 6A, B) from the dark spot at groin, or may be absent in some females (Fig.

377 6D). Variation in size and body proportions of the type series and referred materials is given in

378 Table 2. Females are larger than males: SVL 18.5-23.0 $\mathrm{mm}$ in males $(N=22)$ and 24.2-25.9 $\mathrm{mm}$

379 in females $(N=3)$. Females have comparatively larger body swollen with eggs, and 380 comparatively shorter forelimbs (FLL/SVL mean ratio $77.4 \%(66.7 \%-84.1 \%, N=22)$ in males

381 vs. $66.4 \%(62.4 \%-68.9 \%, N=3)$ in females). Males with single internal vocal sac. Skin texture

382 appears to be less tuberculate in preservative than in life.

383 Distribution and biogeography: The presently known distribution of Micryletta

384

385

386

387

388

389

390

391

392

393

394

395

396

397

398

399

400

nigromaculata sp. nov. is shown in Fig. 1. To date, the new species is known from limestone karst areas covered by primary tropical forest in Cat Ba N. P., Hai Phong Province, and by secondary tropical forest in Cuc Phuong N. P., Ninh Binh Province at elevations 90-150 m a.s.1. Northern Vietnam has one of the world largest areas of limestone landscapes, covered by specific limestone vegetation (Fenart et al., 1999; Day \& Urich, 2000). The currently known range of Micryletta nigromaculata sp. nov. is divided by the vast lowlands of the Red River valley, an important biogeographic border in Indochina (Bain \& Hurley, 2011; Yuan et al., 2016); our phylogenetic analysis estimates genetic divergence between the $\mathrm{Cat} \mathrm{Ba}$ and $\mathrm{Cuc}$ Phuong populations at $0.7 \%$ (see Table 1). It is anticipated that Micryletta nigromaculata sp. nov. also occurs in the adjacent limestone karsts of northern Vietnam; in particular, records from Quang Ninh, Lang Son and Bac Giang provinces of northeastern Vietnam, as well as from Hoa Binh, Ha Nam and Thanh Hoa provinces of northwestern Vietnam are anticipated.

Natural history notes: Our knowledge on the biology of Micryletta nigromaculata sp. nov. is scarce; the species appears to be closely associated with karstic habitats. In Cat Ba N. P. (Hai Phong Province) during a two-week survey in October 2011, specimens were only recorded from a small patch of limestone outcrops ca. $20 \mathrm{~m}$ in diameter, near a large limestone karst cliff and a small temporary body of water. Frogs were observed from 16:00-20:00 h hiding between 
401 small pieces of limestone rocks. Despite intensive search from 10 to 22 of October 2013, no 402 additional specimens of the new species were recorded from other areas in Cat Ba N. P. In Cuc 403 Phuong N. P. (Ninh Binh Province) specimens were found at night between 19:00-23:30 h near 404 cave entrances and in valleys surrounded by limestone cliffs, relatively near to water sources. 405 Surrounding habitat was limestone karst covered with primary polydominant tropical forest with 406 multi-layered canopy and an abundance of lianas, with occasional trees of Streblus macrophyllus 407 (Moraceae), Terminalia myriocarpa (Combretaceae), Parashorea chinensis (Dipterocarpaceae), 408 and Tetrameles nudiflora (Tetramelaceae) (in Cat Ba N.P.) or secondary forest (in Cuc Phuong 409 N.P.). Reproduction biology, including advertisement call, tadpole morphology, as well as diet of 410 the new species remains unknown.

411 Other species of anurans recorded syntopically with the new species at the type locality 412 included Polypedates megacephalus Hallowell, P. mutus (Smith), Theloderma albopunctatum 413 (Liu \& Hu), Liuixalus calcarius Milto, Poyarkov, Orlov \& Nguyen, Philautus catbaensis Milto, 414 Poyarkov, Orlov \& Nguyen, Hyla chinensis Günther, Microhyla butleri Boulenger, M. heymonsi 415 Vogt, and Micryletta cf. inornata. In Cuc Phuong National Park (Ninh Binh Province) the new 416 species was recorded in sympatry with Occidozyga martensii (Peters), Leptobrachium 417 guangxiense Fei, Mo, Ye \& Jiang, Ophryophryne microstoma Boulenger, Glyphoglossus 418 (formerly Calluella) guttulatus (Blyth), Microhyla heymonsi Vogt, Micryletta cf. inornata 419 (Boulenger); Rana johnsi Smith; Sylvirana cf. annamitica Sheridan \& Stuart; Raorchestes cf. 420 menglaensis (Kou); Theloderma albopunctatum (Liu \& Hu), and T. annae Nguyen, Pham, 421 Nguyen, Ngo \& Ziegler.

422 Genetic divergence. The new species is markedly distinct in mtDNA sequences from all 423 congeners for which comparable sequences are available (mitochondrial gene 16S rRNA; 424 uncorrected genetic distance $\geq 5.7 \%$ ) and is reconstructed as a sister lineage with respect to all 425 other examined members of the genus Micryletta.

Comparisons. Micryletta nigromaculata sp. nov. can be distinguished from all other congeners by external morphology and coloration, including presence of characteristic black patches on flanks and the hourglass-shaped irregular dark pattern on dorsum edged with thin orange line. From Micryletta erythropoda (Tarkhnishvili, 1994) (type locality in Dong Nai Province, known from lowlands of southern Vietnam) the new species can be distinguished by 
432 by lacking outer metatarsal tubercle (vs. present in M. erythropoda); by having comparatively 433 longer hindlimbs with tibiotarsal articulation of adpressed limb reaching the level of eye center 434 (vs. reaching the level of the posterior edge of tympanum in M. erythropoda); by having dorsal 435 surface slightly granular with small round flattened tubercles (vs. rather smooth dorsum in $M$. 436 erythropoda); dorsum coloration brown to reddish-brown (vs. grey or beige to saturated ochre or 437 brick-red in M. erythropoda); dorsum pattern with dark-brown irregular hourglass-shaped pattern 438 edged with orange line and with two large black blotches in inguinal area (vs. extremely variable 439 and formed by more or less dark contrasting spots on reddish background in M. erythropoda); 440 lateral sides of head reddish brown without white patches (vs. dark brown with white spotting in 441 M. erythropoda); flanks brown with dark patches or spots edged with white (vs. dark brown to 442 grey with white patches in M. erythropoda); venter whitish with grey pattern (vs. brownish with 443 violet tint in M. erythropoda).

Micryletta nigromaculata sp. nov. can be distinguished from M. inornata (Boulenger, 1890) (type locality in Deli, Sumatra; distributed through Malayan Peninsula to Myanmar, Indochina and southernmost China) by eye length equal or shorter than snout length (vs. snout shorter than the eye in M. inornata); interorbital distance two times wider than upper eyelid width (vs. interorbital space just a little broader than the upper eyelid in M. inornata); dorsum coloration reddish-brown (vs. dark brown to violet in M. inornata); dorsum pattern with darkbrown irregular hourglass-shaped pattern edged with orange line and with two large dark spots in inguinal area (vs. more or less spotted or marbled with black blotches or longitudinal stripes in M. inornata); side of head dark-brown without white patches (vs. black with a series of white spots along the upper lip in $M$. inornata); flanks brown with dark patches or spots edged with white (vs. usually dark brown with white patches in $M$. inornata); venter whitish (vs. lower parts brown in M. inornata); throat in males whitish with light-grey marbling (vs. throat of males black in M. inornata).

Micryletta nigromaculata sp. nov. can be distinguished from M. steinegeri (Boulenger, 1909) (endemic to Taiwan) by having comparatively longer limbs with tibiotarsal articulation of adpressed limb reaching the level of eye center (vs. reaching the level of tympanum in $M$. steinegeri); dorsum coloration brownish to reddish-brown (vs. dark grey to violet in $M$. steinegeri); dorsum pattern with dark-brown irregular hourglass-shaped pattern edged with 
463 with irregular dark blotches or speckles in $M$. steinegeri); side of head uniform brown without 464 white patches (vs. grey-brown with a series of white spots in M. steinegeri); body flanks with 465 dark patches or spots edged with white (vs. flanks usually grey brown with dark marbling in $M$. 466 steinegeri); venter whitish (vs. venter pinkish to orange in M. steinegeri).

Etymology: Specific epithet "nigromaculata" is an adjective in the nominative case, 468 feminine gender, derived from Latin words "niger" for "black" and "maculatus" for "spotted", in reference the characteristic black blotches on flanks in the new species.

Recommended vernacular names: We recommend "Black-spotted Paddy Frog" as the common English name of the new species and the common name in Vietnamese as "Nhái bầu hông đen".

Conservation status: Micryletta nigromaculata sp. nov. is to date known only from two National Parks in northern Vietnam; in both localities frogs were recorded from very narrow specific limestone-associated habitats. It is important to notice that karst massifs in Vietnam, as well as in other parts of Southeast Asia, are facing ongoing severe threats from intensive deforestation and cement manufacturing; their continued exploitation for limestone cannot be stopped (Clements et al., 2006). This may be the major threat for the new species. Despite the actual distribution and population status of Micryletta nigromaculata sp. nov. are unknown, it is obvious that the new species is restricted to isolated highly endangered limestone karst massifs of northern Vietnam. It appears that the new species has strict habitat preferences since it was only recorded in a single locality in Cat Ba National Park (a small part of forest with limestone outcrops with an approximate diameter $100 \mathrm{~m}$ ), and in a single habitat in Cuc Phuong National Park. Despite intensive searching efforts we could not record the new species in other surveyed areas of northern Vietnam. The two localities where the new species was recorded are isolated from each other and separated by a large area of unsuitable habitats - lowlands of the Red River and Gulf of Tonkin (see Fig. 1). At present, the Extent of Occurrence (EOO) of the new species is estimated to be less than $100 \mathrm{~km}^{2}$, is severely fragmented and associated with rapidly declining limestone habitats. Additional surveys in other limestone areas of northern Vietnam are essential for elucidating the biology of the new species. Given the available information, we suggest following IUCN's Red List categories (IUCN, 2016). 
494

495

496

497

498

499

500

501

502

503

504

505

506

507

508

509

510

511

512

513

514

515

516

517

518

519

520

521

522

523

\section{DISCUSSION}

Our study provides an updated mtDNA genealogy and a new data on diversity of the genus Micryletta, which was not studied in detail in recent works on Microhylidae phylogenetics. The key study by Matsui et al. (2011) based on 12S-16S rRNA mtDNA fragment failed to recover phylogenetic placement of Micryletta within Microhylidae and concluded that this genus should be removed from the subfamily Microhylinae to form a distinct monotypic subfamily. These conclusions were not supported by consequent studies used multilocus phylogenetic approach, which all strongly suggested placement of Micryleta within Microhylinae radiation as a sister taxon to the group composed of Microhyla and Glyphoglossus (Peloso et al., 2016), or as a sister lineage of the clade joining Uperodon, Phrynella, Metaphrynella and Kaloula (Tu et al., 2018). Our study, though with moderate node support (0.94/78), places Micryletta as a sister lineage to the latter clade in agreement with results of Tu et al. (2018).

Matsui et al. (2011), based on analyses of three specimens of Micryletta, further showed that $M$. inornata was paraphyletic with respect to $M$. steinegeri, and argued that a sample of Micryletta sp. from Ranong Province in southern Thailand (which they identified as M. $i$. lineata) is more divergent than M. inornata from northern Thailand and M. steinegeri from Taiwan. Our study revealed a previously unknown species of Micryletta in northern Vietnam, which is proposed as a sister lineage with respect to all other examined populations (see Fig. 2). We also analyzed genealogical relationships between 17 samples of Micryletta from Vietnam, Laos, Thailand and Taiwan, including two topotype specimens of M. erythropoda from southern Vietnam and two populations of $M$. cf. inornata from northern Vietnam which are sympatric with the new species. Our data showed that M. erythropoda samples cluster with Micryletta sp. from Ranong Province and together they form a sister lineage with respect to all other populations of $M$. cf. inornata from Indochina and $M$. steinegeri from Taiwan. This lineage is clearly divergent from other $M$. inornata populations $(4.6 \%-5.9 \%$ in $16 \mathrm{~S}$ rRNA gene; see Table 1) suggesting that $M$. erythropoda represents a distinct species, which occurs in lowlands of southern Vietnam and, possibly, also in southern Thailand. If identification by Matsui et al. (2011) is correct, the name M. inornata lineata (Taylor, 1962) should have the priority over $M$. erythropoda Tarkhnishvili, 1994. However, inclusion of topotype specimens of $M$. inornata lineata from Nakhon Si Thammarat Province of Thailand is required to revise this problem. 
524

525

526

527

528

529

530

531

532

533

534

535

536

537

538

539

540

541

542

543

544

545

546

547

548

549

550

551

552

553

554

In our phylogeny (see Fig. 2) M. steinegeri from Taiwan was nested within the radiation of M. cf. inornata from mainland Indochina; the Taiwanese sample was only slightly divergent from M. cf. inornata (2.8\% from M. cf. inornata group A, and only $1.3 \%$ from $M$. cf. inornata group B; see Table 1). Mainland populations of $M$. cf. inornata are grouped in several moderately divergent lineages, which also show significant variation in coloration (see Fig. 2), suggesting that taxonomy of this group might be incomplete. The revision of $M$. inornata $-M$. steinegeri group is currently not possible due to the lack of comparative materials from the type locality of $M$. inornata from Sumatra. However, all representatives of $M$. inornata $-M$. steinegeri complex, as well as $M$. erythropoda, can be easily diagnosed from the new species since they share several important diagnostic characters:

A certain degree of white spotting or the upper lip (see Fig. 2), whereas in $M$. nigromaculata upper lip is always dark brown lacking white markings (see Fig. 6). This character is also mentioned in the original description of $M$. inornata by Boulenger (1890) ("sides of head black, with a series of white spots along the upper lip"), reassuring us that the new species cannot be confused with $M$. inornata s.stricto.

(2) Another important character is the relative length of snout, which is notably shorter than eye in all species of Micryletta, including M. inornata s.str. (Boulenger, 1890) but is subequal to eye length in the new species (SL/EL $85.1 \%-104.5 \%$, mean $94.5 \%$ ).

(3) Throat in breeding males is dark (black to dark-grey) in all Micryletta species including the M. inornata s.stricto (Boulenger, 1890), but is whitish with grey marbling in M. nigromaculata.

(4) Finally, the presence of dark inguinal spots was never reported for members of $M$. inornata - M. steinegeri complex, including the original description of $M$. inornata (Boulenger, 1890), but is characteristic for all examined specimens of M. nigromaculata.

Due to the wide range of M. inornata sensu lato (from northeast India through Myanmar to Indochina, Malay Peninsula and Sumatra) additional materials and further studies on many populations, especially from Sumatra, are critically required to solve taxonomic problems in this group. 
Our study provides new evidence for previously unknown diversity of herpetofauna of 556 karstic areas in Northern Vietnam. Previous studies in limestone massifs of Cat Ba Island in Ha 557 Long Bay uncovered two new species of frogs (Milto et al., 2013) and one new species of gecko 558 (Ziegler et al., 2008) all of which are endemic to the island and strongly associated with karst 559 habitats. Cuc Phuong National Park and adjacent limestone massifs are also known for karst560 associated endemism with a new species of gecko discovered from karst formations in this area 561 (Ngo \& Chan, 2011). Limestone karst massifs in northern Vietnam are divided by the Red River 562 valley, an important biogeographic border in northern Indochina (Bain \& Hurley, 2011; Geissler 563 et al., 2015; Yuan et al., 2016). The discovery of M. nigromaculata population in Cuc Phuong 564 National Park, on the other side of the Red River valley (see Fig. 1) provide further evidence for 565 interconnection of limestone karst herpetofauna in northern Vietnam. Despite certain divergence 566 in mtDNA $16 \mathrm{~S}$ rRNA gene $(0.7 \%)$, overall morphological similarity of the Cuc Phuong and Cat 567 Ba populations of $M$. nigromaculata suggest they belong to a single species.

568 It is also remarkable, that in both localities M. nigromaculata was recorded in sympatry 569 with $M$. cf. inornata, different from the new species both morphologically and genetically (see 570 Fig. 2). The two coexisting species of Micryletta however never were observed to share the same 571 habitats, since M. nigromaculata was always restricted to very narrow patches of karstic 572 limestone outcrops where $M$. cf. inornata was not observed.

573

\section{CONCLUSIONS}

575 Limestone karst areas are recognized as arks of highly endangered though still 576 insufficiently studied biodiversity. Unique geological structure of karst massifs, formed by 577 erosion and subterranean water drainages create numerous humid microrefugia with stable 578 environmental conditions, which serve as an important environmental buffer for small 579 vertebrates during periods of climate change (Clements et al., 2006; Glaw et al., 2006). The 580 complex terrain of isolated karstic hills and caves create multiple ecological niches what along 581 with their highly fragmented habitat-island nature result in high degrees of site-specific 582 endemism within, and diversity among them (Oliver et al., 2017; Grismer et al., 2018). 583 Limestone karsts are also known as important "biodiversity arks" for both surface and cave 584 faunas, yet karstic regions are rapidly becoming some of the most imperiled ecosystems on the 585 planet (Clements et al., 2006; Grismer et al., 2016a, 2016b, 2018; Luo et al., 2016; 
586 Suwannapoom et al., 2018). South-east Asia harbours more limestone karsts than anywhere else 587 on earth (Day \& Urich, 2000) with numerous new species including relic lineages of amphibians 588 and reptiles being discovered from limestone areas (e.g. see discussions in Milto et al., 2013; 589 Grismer et al., 2014; Grismer \& Grismer, 2017; Grismer et al., 2016a, 2016b, 2017, 2018; 590 Nazarov et al., 2014, 2018; Connette et al., 2017; Suwannapoom et al., 2018 and references 591 therein). Ironically, though acting as major biodiversity hotspots, limestone karsts are critically 592 endangered due to unregulated quarrying mostly for cement manufacturing, which is the primary 593 threat to the survival of karst-associated species (Grismer et al., 2018); their continued 594 exploitation for limestone cannot be stopped (Clements et al., 2006). Until karst habitats in 595 Vietnam are thoroughly investigated, a significant portion of this country's herpetological 596 diversity will remain underestimated and unprotected. Our study thus calls for urgent focused 597 survey and conservation efforts on karst herpetofauna in Southeast Asia and in Vietnam in 598 particular.

599

600 ACKNOWLEDGEMENTS

601 We would like to thank the Department of Forestry, Ministry of Agriculture and Rural 602 Development of Vietnam and the Forest Protection Departments of the Hai Phong and Ninh Binh 603 provinces for supporting our fieldwork and issuing relevant permits. NAP thanks Andrei N. 604 Kuznetsov (JVRTRTC, Vietnam), Leonid P. Korzoun (MSU, Russia) and Vyacheslav V. 605 Rozhnov (IPEE RAS, Russia) and Nguyen Dang Hoi (JVRTRTC, Vietnam) for organizing and 606 supporting his work in Vietnam. TVN thanks Thai Van Nguyen, Dung Van Le (SVW, Vietnam) 607 for organizing and supporting his work in Vietnam. We thank Eduard A. Galoyan, Alina V. 608 Alexandrova, Evgeniy S. Popov, Mikhail V. Kalyakin, Sergei V. Kruskop, Alexei V. Abarmov, 609 Paul Freed, Olesya, Maxim and Stanislav Pavlovs' (Russia) and Tan Nhat La (Hanoi) for help, 610 support and encouragement during the fieldwork. We thank Le Xuan Son for help in the field 611 and continuous support. NAP thanks Valentina D. Kretova for help with preparation of figures, 612 Evgeniya N. Solovyeva for help with primer design, and Alexandra A. Elbakyan for help with 613 accessing required literature. We are deeply grateful to Nikolai L. Orlov (ZISP, St. Petersburg, 614 Russia) and Roman A. Nazarov (ZMMU, Moscow, Russia) for fruitful discussions. We are 615 indebted to Valentina F. Orlova (ZMMU, Moscow, Russia), Natalia B. Ananjeva (ZISP, St. 616 Petersburg, Russia) and Ying-Yong Wang (SYS, Guangzhou, China) for providing working 
617 facilities and an access to the collections under their care. We would like to express our gratitude 618 to Marcio Pie, Mark D. Scherz and an anonymous reviewer for useful comments on the earlier 619 version of this manuscript.

620

621

622

623

624

625

626

627

628

629

630

631

632

633

634

635

636

637

638

639

640

641

642

643

644

645

646

647

\section{REFERENCES}

AmphibiaWeb. 2018. Information on Amphibian Biology and Conservation [web application], Berkeley, California: AmphibiaWeb. Available from http:amphibiaweb.org (accessed 15 July 2018).

Bain RH, Nguyen TQ. 2004. Three new species of narrow-mouth frogs (Genus: Microhyla) from Indochina, with comments on Microhyla annamensis and Microhyla palmipes. Copeia 2004(3):507-524. DOI:10.1643/ch-04-020r2

Bain RH, Hurley MM. 2011. A biogeographic synthesis of the Amphibians and Reptiles of Indochina. Bulletin of the American Museum of Natural History 360:1-138.

Boulenger GA. 1890. List of the reptiles, batrachians, and freshwater fishes collected by Professor Moesch and Mr. Iversen in the district of Deli, Sumatria. Proceedings of the Zoological Society of London 1890:30-39.

Boulenger GA. 1909. Descriptions of four new frogs and a new snake discovered by Mr. H. Sauter in Formosa. Annals and Magazine of Natural History, Series 8 4:492-495.

Clements R, Sodhi NS, Schilthuizen M, Ng PKL. 2006. Limestone Karsts of Southeast Asia: Imperiled Arks of Biodiversity. BioScience 56(09):733-746.

Connette GM, Oswald P, Thura MK, Connette KJL, Grindley ME, Songer M, Zug GR, Mulchay DG. 2017. Rapid forest clearing in a Myanmar proposed national park threatens two newly discovered species of geckos (Gekkonidae: Cyrtodactylus). PloS One 12: 0174432.

Day M, Urich P. 2000. An assessment of protected karst landscapes in Southeast Asia. Cave and Karst Science 27:61-70.

Dubois A. 1987. Miscelanea taxinomica batrachologica, II. Alytes 6:1-9.

Fei L, Hu SQ, Ye CY, Huang Y. 2009. Fauna Sinica. Amphibia. Volume 2. Anura. Chinese Academy of Science, Science Press, Beijing.

Fei L, Ye C, Jiang J. 2010. Colored Atlas of Chinese Amphibians. Sichuan Publishing House of Science \& Technology, Sichuan. 
648 Felsenstein J. 1985. Confidence limits on phylogenies: an approach using the bootstrap. 649 Evolution 39(4):783-791. DOI:10.2307/2408678

650 Fenart P, Cat NN, Drogue C, Doan VC, Pistre S. 1999. Influence of tectonics and 651

652 neotectonics on the morphogenesis of the peak karst of Halong Bay, Vietnam. Geodinamica Acta 12:193-200.

653

Frost DR. 2018. Amphibian species of the World 6.0, an online reference. (2018-08). New York: 654

655

656

Darrel Frost and the American Museum of Natural History. http://research.amnh.org/herpetology/amphibia/index.html (accessed 15 July

657

658

659

660

661

662

663

664

665

666

667

668

669

670

671

672

673

674

675

676

677 2018).

Geissler P, Hartmann T, Ihlow F, Rödder D, Poyarkov NA, Nguyen TQ, Ziegler T, Böhme W. 2015. The Lower Mekong: an insurmountable barrier to amphibians in southern Indochina? Biological Journal of the Linnean Society 114(4):905-914. DOI:10.1111/bij.12444

Glaw F, Hoegg S, Vences M. 2006. Discovery of a new basal relict lineage of Madagascan frogs and its implications for mantellid evolution. Zootaxa 1334:27-43.

Glaw F, Vences M. 1997. Anuran eye colouration: definitions, variation, taxonomic implications and possible functions. In: Böhme W, Bischoff W, Ziegler $\mathrm{T}$ (Eds.) Herpetologia Bonnensis. SEH Proceedings, Bonn: 125-138.

Global Mapper. 2009. Global Mapper 10.0, Global Mapper Software LLC, PO Box 3051, Olathe, KS 66063, USA, www.globalmapper.com

Grismer LL, Grismer JL. 2017. A re-evaluation of the phylogenetic relationships of the Cyrtodactylus condorensis group (Squamata; Gekkonidae) and a suggested protocol for the characterization of rock-dwelling ecomorphology in Cyrtodactylus. Zootaxa 4300(4):486-504. DOI:10.11646/zootaxa.4300.4.2

Grismer LL, Wood PL Jr, Myint Kyaw Thura, Thaw Zin, QUah ESH, Murdoch ML, Grismer MS, Aung Lin, Htet Kyaw, Ngwe Lwin. 2017. Twelve new species of Cyrtodactylus Gray (Squamata: Gekkonidae) from isolated limestone habitats in east, central and southern Myanmar demonstrate high localized diversity and unprecedented microendemism. Zoological Journal of the Linnean Society 45(306-07):251-484. DOI:10.1111/j.1096-3642.1965.tb00500.x 
678 Grismer LL, Wood PL Jr., Anuar S, Grismer MS, Muin MA, Davis HR, Aguilar C,

679

680

681

682

683

684

685

686

687

688

689

690

691

692

693

694

695

696

697

698

699

700

701

702

703

704

705

706

707

708

Klaback R, Cobos AJ, Aowphol A, Sites JW. 2016a. Two new Bent-toed Geckos of the Cyrtodactylus pulchellus complex from Peninsular Malaysia and multiple instances of convergent adaptation to limestone forest ecosystems. Zootaxa 4105:401-429.

Grismer LL, Wood PL Jr., Anuar S, Quah ESH, Muin MA, Mohamed M, Chan KO, Sumarli AX, Loredo AI, Heinz HM. 2014. The phylogenetic relationships of three new species of the Cyrtodactylus pulchellus complex (Squamata: Gekkonidae) from poorly explored regions in northeastern Peninsular Malaysia. Zootaxa 3786:359-381.

Grismer LL, Wood PL, Aowphol A, Cota M, Grismer MS, Murdoch M, Aguilar C, Grismer JL. 2016b. Out of Borneo, again and again: biogeography of the Stream Toad genus Ansonia Stoliczka (Anura: Bufonidae) and the discovery of the first limestone cave-dwelling species. Biological Journal of Linnean Society DOI:10.1111/bij.12886/abstract.

Grismer LL, Wood PL, Myint Kyaw Thura, Quah ESH, Murdoch ML, Grismer MS, Herr MW, Aung Lin, Htet Kyaw. 2018. Three more new species of Cyrtodactylus (Squamata: Gekkonidae) from the Salween Basin of eastern Myanmar underscore the urgent need for the conservation of karst habitats. Journal of Natural History 52(1920):1243-1294.

Hall TA. 1999. BioEdit: a user-friendly biological sequence alignment editor and analysis program for Windows 95/98/NT. In: Nucleic acids symposium series. [London]: Information Retrieval Ltd., c1979-c2000:95-98.

Hedges SB. 1994. Molecular evidence for the origin of birds. Proceedings of the National Academy of Sciences 91(7):2621-2624. DOI:10.1073/pnas.91.7.2621

Hillis DM, Moritz C, Mable BK. 1996. Molecular Systematics. 2nd ed. Sunderland, Massachusetts, U.S.A: Sinauer Associates, 655 pp.

Huelsenbeck JP, Hillis DM. 1993. Success of phylogenetic methods in the four-taxon case. Systematic Biology 42(3):247-264. DOI:10.2307/2992463

Huelsenbeck JP, Ronquist F. 2001. MRBAYES: Bayesian inference of phylogenetic trees. Bioinformatics 17(8):754-755. DOI:10.1093/bioinformatics/17.8.754

IUCN Standards and Petitions Subcommittee. 2016. Guidelines for Using the IUCN Red List Categories and Criteria. Version 12. Prepared by the Standards and Petitions 
709

710

711

712

713

714

715

716

717

718

719

720

721

722

723

724

725

726

727

728

729

730

731

732

733

734

735

736

737

Subcommittee.

Downloadable

from:

http://www.iucnredlist.org/documents/RedListGuidelines.pdf (accessed on 15 August 2018).

Luo Z, Tang S, Jiang Z, Chen J, Fang H, Li C. 2016. Conservation of terrestrial vertebrates in a global hotspot of karst in southwestern China. Scientific Reports DOI:10.10.38/srep25717

Matsui M, Shimada T, Liu W-Z, Maryati M, Khonsue W, Orlov N. 2006. Phylogenetic relationships of Oriental torrent frogs in the genus Amolops and its allies (Amphibia, Anura, Ranidae). Molecular Phylogenetics and Evolution 38(3):659-666. DOI:10.1016/j.ympev.2005.11.019

Matsui M, Hamidy A, Belabut DM, Ahmad N, Panha S, Sudin A, Khonsue W, Oh HS, Yong HS, Jiang J, Nishikawa K. 2011. Systematic relationships of Oriental tiny frogs of the family Microhylidae (Amphibia, Anura) as revealed by mtDNA genealogy. Molecular Phylogenetics and Evolution 61:167-176.

Matsui M, Busack SD. 1985. A reassessment of the taxonomic status of Rana gracilipes Gressitt, 1938 from Taiwan. Herpetologica 41(2):159-160.

Milto KD, Poyarkov NA, Orlov NL, Nguyen TT. 2013. Two new rhacophorid frogs from Cat Ba Island, Gulf of Tonkin (Hai Phong Province, Vietnam). Russian Journal of Herpetology 20(4):287-300.

Nazarov R.A., Pauwels O.S.G., Konstantinov E.L., Chulisov A.S., Orlov N.L., Poyarkov N.A. 2018. A new karst-dwelling bent-toed gecko (Squamata: Gekkonidae: Cyrtodactylus) from Xiangkhoang Province, northeastern Laos. Zoological Research 38(3):197-213.

Nazarov RA, Poyarkov NA, Orlov NL, Nguyen NS, Milto KD, Martynov AA, Konstantinov EL, Chulisov AS. 2014. A review of Cyrtodactylus (Reptilia: Sauria: Geckonidae) fauna of Laos with description of four new species. Proceedings of the Zoological Institute RAS 318(4):391-423.

Ngo TV, Chan KO. 2011. A new karstic cave-dwelling Cyrtodactylus Gray (Squamata: Gekkonidae) from Northern Vietnam. Zootaxa, 3125: 51-63. 
738

739

740

741

742

743

744

745

746

747

748

749

750

751

752

753

754

755

756

757

758

759

760

761

762

763

764

765

766

767

Nguyen LT, Poyarkov NA, Nguyen TT, Nguyen TA, Nguyen VH, Gorin VA, Murphy RW, Nguyen SN. 2018. A new species of the genus Microhyla Tschudi, 1838 (Amphibia: Anura: Microhylidae) from Tay Nguyen Plateau, Central Vietnam. Zootaxa, in press.

Oliver PM, Laver RJ, De Mello Martins F, Pratt RC, Hunjan S, Moritz CC. 2017. A novel hotspot of vertebrate endemism and an evolutionary refugium in tropical Australia. Diversity and Distributions 23:53-66.

Orlov NL, Murphy RW, Ananjeva NB, Ryabov SA, Ho CT. 2002. Herpetofauna of Vietnam, a checklist. Part 1. Amphibia. Russian Journal of Herpetology 9:81-104.

Parker HW. 1928. The brevicipitid frogs of the genus Microhyla. Annals and Magazine of Natural History 10(2):473-499.

Parker HW. 1934. A monograph of the frogs of the family Microhylidae. London: Trustees of the British Museum.

Peloso PL, Frost DR, Richards SJ, Rodrigues MT, Donnellan S, Matsui M, Raxworthy CJ, Biju S, Lemmon EM, Lemmon AR. 2016. The impact of anchored phylogenomics and taxon sampling on phylogenetic inference in narrow-mouthed frogs (Anura, Microhylidae). Cladistics 32(2):113-140. DOI:10.1111/cla.12118

Posada D, Crandall KA. 1998. Modeltest: testing the model of DNA substitution. Bioinformatics 14(9):817-818. DOI:10.1093/bioinformatics/14.9.817

Poyarkov NA, Vassilieva AB, Orlov NL, Galoyan EA, Tran TT, Le DTT, Kretova VD, Geissler P. 2014. Taxonomy and distribution of narrow-mouth frogs of the genus Microhyla Tschudi, 1838 (Anura: Microhylidae) from Vietnam with descriptions of five new species. Russian Journal of Herpetology 21(2):89-148.

Pyron RA, Wiens JJ. 2011. A large-scale phylogeny of Amphibia including over 2800 species, and a revised classification of advanced frogs, salamanders, and caecilians. Molecular Phylogenetics and Evolution 61:543-583.

Rakotoarison A, Scherz MD, Glaw F, Ko“hler J, Andreone F, Franzen M, Glos J, Hawlitschek O, Jono T, Mori A, Ndriantsoa SH, Raminosoa NR, Riemann JC, Ro“del MO, Rosa GM, Vieites DR, Crottini A, Vences M. 2017. Describing the smaller majority: integrative taxonomy reveals twenty-six new species of tiny microhylid frogs (genus Stumpffia) from Madagascar. Vertebrate Zoology 67(3):271-398. 
768

769

770

771

772

773

774

775

776

777

778

779

780

781

782

783

784

785

786

787

788

789

790

791

792

793

794

795

796

797

798

Ronquist F, Huelsenbeck JP. 2003. MrBayes 3: Bayesian phylogenetic inference under mixed models. Bioinformatics 19(12):1572-1574. DOI:10.1093/bioinformatics/btg180

Sambrook J, David W. 2001. Molecular cloning: a laboratory manual, 3rd edn.. Plainview. Cold Spring Harbor Laboratory Press, New York.

Savage JM. 1975. Systematics and distribution of the Mexican and Central American stream frogs related to Eleutherodactylus rugulosus. Copeia 2:254-306.

Stamatakis A, Hoover P, Rougemont J. 2008. A rapid bootstrap algorithm for the RAxML web servers. Systematic Biology, 57(5):758-771. DOI:10.1080/10635150802429642

Suwannapoom C, Sumontha M, Tunprasert J, Ruangsuwan T, Pawangkhanant P, Korost DV, Poyarkov NA. 2018. A striking new genus and species of cave-dwelling frog (Amphibia: Anura: Microhylidae: Asterophryinae) from Thailand. PeerJ 6:e4422. DOI: $10.7717 /$ peerj.4422.

Tamura K, Stecher G, Peterson D, Filipski A, Kumar S. 2013. MEGA6: molecular evolutionary genetics analysis version 6.0. Molecular Biology and Evolution 30(12):2725-2729. DOI:10.1093/molbev/mst197

Tarkhnishvili DN. 1994. Amphibian communities of the southern Viet Nam: Preliminary data. Journal of the Bengal Natural History Society, New Series 13(1):3-62.

Taylor EH. 1962. The amphibian fauna of Thailand. University of Kansas Science Bulletin 43:265-599.

Thompson JD, Gibson TJ, Plewniak F, Jeanmougin F, Higgins DG. 1997. The CLUSTAL_X windows interface: flexible strategies for multiple sequence alignment aided by quality analysis tools. Nucleic acids research 25(24):4876-4882. DOI:10.1093/nar/25.24.4876

Tu N, Yang MH, Liang D, Zhang P. 2018. A large-scale phylogeny of Microhylidae inferred from a combined dataset of 121 genes and 427 taxa. Molecular Phylogenetics and Evolution 126:85-91.

Van der Meijden A, Vences M, Hoegg S, Boistel R, Channing A, Meyer A. 2007. Nuclear gene phylogeny of narrow-mouthed toads (Family: Microhylidae) and a discussion of competing hypotheses concerning their biogeographical origins. Molecular Phylogenetics and Evolution 44:1017-1030.

Vences M, Thomas M, Bonett RM, Vieites DR. 2005a. Deciphering amphibian diversity through DNA barcoding: chances and challenges. Philosophical Transactions of the 
799

800

801

802

803

804

805

806

807

808

809

810

811

812

813

814

815

816

817

818

Royal Society of London B: Biological Sciences 360(1462):1859-1868. DOI:10.1098/rstb.2005.1717

Vences M, Thomas M, van der Meijden, A, Chiari Y, Vieites DR. 2005b. Comparative performance of the 16S rRNA gene in DNA barcoding of amphibians. Frontiers in zoology 2(1):5.

Vieites DR, Wollenberg KC, Andreone F, Köhler J, Glaw F, Vences M. 2009. Vast underestimation of Madagascar's biodiversity evidenced by an integrative amphibian inventory. Proceedings of the National Academy of Sciences 106(20):8267-8272. DOI:10.1073/pnas.0810821106

Wang CS, Wu SH, Yu HT. 1989. Notes on Microhyla inornata Boulenger (Anura: Microhylidae) in Taiwan. Journal of Herpetology 23(4):342-349.

Yuan ZY, Suwannapoom C, Yan F, Poyarkov NA, Nguyen NS, Siriwadee C, Murphy RW, Zhang YP, Che J. 2016. Red River barrier and Pleistocene climatic fluctuations shaped the genetic structure of Microhyla fissipes complex (Anura: Microhylidae) in southern China and Indochina. Current Zoology 2016:1-13.

Zhao EM, Adler K. 1993. Herpetology of China. Ithaca: Society for the Study of Amphibians and Reptiles.

Ziegler T, Nguyen TQ, Schmitz A, Stenke R, Rösler H. 2008. A new species of Goniurosaurus from Cat $\mathrm{Ba}$ Island, Hai Phong, northern Vietnam (Squamata: Eublepharidae). Zootaxa 1771:16-30. 


\section{Table $\mathbf{1}$ (on next page)}

Uncorrected p-distance (percentage) between 16S rRNA sequences of Micryletta and other microhylids included in the phylogenetic analyses (below the diagonal), and standard error estimates (above the diagonal).

The ingroup mean uncorrected $p$-distances are shown on the diagonal and shaded with grey. 


\begin{tabular}{|c|c|c|c|c|c|c|c|c|c|c|c|c|c|c|c|}
\hline & Taxon & 1 & 2 & 3 & 4 & 5 & 6 & 7 & 8 & 9 & 10 & 11 & 12 & 13 & 14 \\
\hline \multicolumn{16}{|c|}{ Ingroup: Micryletta } \\
\hline 1 & M. nigromaculata sp. nov. & 0.7 & 1.2 & 1.1 & 1.2 & 1.1 & 1.4 & 1.4 & 1.4 & 1.3 & 1.4 & 1.6 & 1.3 & 1.7 & 1.5 \\
\hline 2 & M. cf. inornata A & 7.2 & 2.2 & 0.7 & 0.6 & 1.0 & 1.5 & 1.4 & 1.4 & 1.4 & 1.4 & 1.6 & 1.4 & 1.8 & 1.6 \\
\hline 3 & M. cf. inornata B & 5.9 & 2.5 & 0.1 & 0.5 & 0.9 & 1.5 & 1.4 & 1.4 & 1.4 & 1.4 & 1.7 & 1.4 & 1.8 & 1.5 \\
\hline 4 & M. steinegeri & 5.9 & 2.8 & 1.4 & - & 0.9 & 1.5 & 1.4 & 1.4 & 1.4 & 1.4 & 1.6 & 1.4 & 1.8 & 1.6 \\
\hline 5 & M. erythropoda & 7.7 & 5.9 & 4.6 & 5.5 & 1.7 & 1.5 & 1.4 & 1.4 & 1.3 & 1.4 & 1.6 & 1.3 & 1.7 & 1.6 \\
\hline \multicolumn{16}{|c|}{ Outgroup } \\
\hline 6 & Microhyla I & 10.5 & 11.4 & 11.4 & 10.8 & 12.1 & - & 1.4 & 1.5 & 1.3 & 1.6 & 1.8 & 1.7 & 2.0 & 1.4 \\
\hline 7 & Microhyla II & 12.4 & 12.7 & 12.5 & 12.0 & 13.4 & 12.0 & 7.3 & 1.3 & 1.4 & 1.6 & 1.6 & 1.5 & 1.7 & 1.5 \\
\hline 8 & Glyphoglossus & 12.0 & 12.5 & 12.1 & 11.8 & 13.6 & 11.9 & 12.4 & 8.6 & 1.3 & 1.3 & 1.6 & 1.5 & 1.6 & 1.5 \\
\hline 9 & Kaloula & 12.3 & 12.6 & 12.2 & 12.2 & 12.8 & 11.6 & 14.2 & 14.1 & 6.8 & 1.1 & 1.4 & 1.3 & 1.7 & 1.4 \\
\hline 10 & Uperodon & 13.6 & 13.5 & 12.9 & 13.3 & 13.3 & 13.3 & 14.7 & 12.1 & 10.0 & - & 1.6 & 1.3 & 1.9 & 1.6 \\
\hline 11 & Phrynella & 14.7 & 13.8 & 13.5 & 12.9 & 14.4 & 15.0 & 14.9 & 15.5 & 12.3 & 12.9 & - & 1.2 & 2.0 & 1.6 \\
\hline 12 & Metaphrynella & 14.2 & 13.1 & 13.0 & 12.5 & 14.7 & 14.4 & 14.9 & 15.8 & 11.7 & 11.9 & 8.2 & 7.1 & 1.9 & 1.5 \\
\hline 13 & Chaperina & 16.1 & 17.7 & 17.2 & 16.9 & 17.0 & 18.1 & 18.3 & 16.0 & 19.6 & 21.5 & 19.6 & 20.6 & - & 1.9 \\
\hline 14 & Kalophrynus & 12.9 & 14.7 & 14.0 & 13.9 & 15.2 & 13.6 & 13.3 & 15.2 & 15.6 & 16.7 & 16.7 & 15.6 & 19.4 & - \\
\hline
\end{tabular}

3 


\section{Table 2 (on next page)}

Measurements of the type series and referred materials on Micryletta nigromaculata sp. nov.

For character abbreviations see Materials and methods. 
1

\begin{tabular}{|c|c|c|c|c|c|c|c|c|c|c|c|c|c|c|c|c|c|c|c|c|}
\hline № & Specimen ID & $\begin{array}{c}\text { Type } \\
\text { status }\end{array}$ & SVL & HL & SL & EL & N-EL & HW & IND & IOD & UEW & TYD & FLL & LAL & HAL & 1FL & IPTL & OPTL & 3FDD & HLL \\
\hline & Males & & & & & & & & & & & & & & & & & & & \\
\hline 1 & ZMMU A5934 & holotype & 22.7 & 6.9 & 2.7 & 2.9 & 1.9 & 8.1 & 2.2 & 3.3 & 1.8 & 1.2 & 16.3 & 12.3 & 7.0 & 2.0 & 0.6 & 0.8 & 0.5 & 34.7 \\
\hline 2 & ZMMU A5935 & paratype & 18.7 & 6.2 & 2.9 & 2.6 & 1.6 & 6.9 & 1.8 & 2.7 & 1.5 & 1.1 & 14.7 & 10.7 & 5.8 & 2.0 & 0.5 & 1.2 & 0.4 & 31.1 \\
\hline 3 & ZMMU A5936 & paratype & 18.8 & 5.9 & 2.6 & 2.5 & 1.6 & 6.7 & 1.8 & 2.5 & 1.5 & 0.9 & 13.3 & 9.8 & 5.3 & 1.8 & 0.5 & 0.7 & 0.4 & 30.7 \\
\hline 4 & ZMMU A5937 & paratype & 19.8 & 6.4 & 2.9 & 2.5 & 1.8 & 7.3 & 2.0 & 3.0 & 1.4 & 1.0 & 16.1 & 11.4 & 6.0 & 2.1 & 0.6 & 0.7 & 0.4 & 33.7 \\
\hline 5 & ZMMU A5938 & paratype & 20.4 & 6.7 & 2.9 & 2.7 & 1.8 & 7.4 & 1.9 & 2.9 & 1.5 & 1.2 & 16.8 & 12.1 & 6.2 & 2.1 & 0.6 & 0.8 & 0.4 & 35.4 \\
\hline 6 & ZMMU A5939 & paratype & 20.4 & 6.8 & 2.9 & 2.6 & 1.9 & 6.9 & 2.1 & 3.0 & 1.5 & 1.2 & 15.6 & 11.4 & 6.0 & 2.4 & 0.5 & 0.8 & 0.5 & 35.3 \\
\hline 7 & SYS a007400 & paratype & 20.4 & 6.3 & 2.9 & 2.5 & 1.9 & 7.0 & 1.9 & 2.9 & 1.5 & 1.0 & 16.1 & 11.3 & 5.8 & 2.2 & 0.6 & 0.7 & 0.5 & 35.5 \\
\hline 8 & ZMMU A5940 & paratype & 20.7 & 6.6 & 2.9 & 2.8 & 1.8 & 6.9 & 2.0 & 3.0 & 1.7 & 1.3 & 15.3 & 11.4 & 5.7 & 2.0 & 0.6 & 0.8 & 0.4 & 34.6 \\
\hline 9 & ZMMU A5941 & paratype & 20.7 & 6.6 & 2.9 & 2.8 & 1.8 & 7.2 & 2.0 & 3.0 & 1.6 & 1.1 & 17.1 & 11.9 & 6.1 & 2.1 & 0.6 & 0.8 & 0.5 & 35.6 \\
\hline 10 & ZMMU A5942 & paratype & 21.9 & 6.8 & 3.0 & 2.6 & 2.0 & 7.5 & 1.9 & 3.1 & 1.6 & 1.0 & 18.2 & 12.5 & 6.4 & 2.2 & 0.7 & 0.7 & 0.4 & 35.9 \\
\hline 11 & ZMMU A5943 & paratype & 22.0 & 6.7 & 2.9 & 2.6 & 1.8 & 7.4 & 2.2 & 3.2 & 1.5 & 1.1 & 17.7 & 13.1 & 6.9 & 2.8 & 0.6 & 0.8 & 0.5 & 39.0 \\
\hline 12 & ZMMU A5944 & paratype & 22.0 & 7.1 & 2.9 & 3.0 & 1.8 & 7.7 & 2.0 & 3.1 & 1.5 & 1.1 & 16.8 & 12.6 & 6.5 & 2.3 & 0.7 & 0.7 & 0.5 & 37.2 \\
\hline 13 & ZMMU A5945 & paratype & 22.3 & 6.9 & 3.1 & 2.8 & 1.9 & 7.1 & 2.0 & 3.1 & 1.6 & 1.2 & 17.2 & 12.7 & 6.7 & 2.4 & 0.5 & 0.8 & 0.5 & 38.2 \\
\hline 14 & ZMMU A5946 & paratype & 22.6 & 6.7 & 2.9 & 2.9 & 1.9 & 8.0 & 1.9 & 3.0 & 1.6 & 1.2 & 16.8 & 12.7 & 6.5 & 2.2 & 0.6 & 0.8 & 0.4 & 36.5 \\
\hline 15 & ZMMU A5947 & paratype & 22.8 & 7.1 & 3.0 & 2.6 & 1.8 & 7.5 & 1.9 & 3.0 & 1.6 & 1.2 & 17.8 & 13.0 & 7.1 & 2.5 & 0.6 & 0.9 & 0.5 & 39.0 \\
\hline 16 & ZMMU A5948 & paratype & 23.0 & 7.3 & 3.0 & 2.6 & 1.9 & 7.8 & 2.1 & 3.0 & 1.6 & 1.1 & 18.6 & 13.1 & 7.0 & 2.7 & 0.5 & 0.9 & 0.5 & 38.7 \\
\hline 17 & DTU 301 & - & 18.5 & 5.7 & 2.4 & 2.5 & 1.6 & 6.1 & 1.9 & 2.6 & 1.4 & 1.0 & 13.3 & 9.6 & 5.3 & 2.1 & 0.5 & 0.8 & 0.4 & 31.3 \\
\hline \multirow[t]{6}{*}{18} & DTU 302 & - & 20.0 & 5.8 & 2.6 & 2.7 & 1.7 & 6.4 & 2.1 & 3.0 & 1.6 & 1.0 & 13.3 & 9.9 & 5.5 & 2.1 & 0.6 & 0.9 & 0.5 & 31.7 \\
\hline & & Mean & 21.0 & 6.6 & 2.8 & 2.7 & 1.8 & 7.2 & 2.0 & 3.0 & 1.5 & 1.1 & 16.2 & 11.7 & 6.2 & 2.2 & 0.6 & 0.8 & 0.5 & 35.2 \\
\hline & & SD & 1.5 & 0.5 & 0.2 & 0.1 & 0.1 & 0.5 & 0.1 & 0.2 & 0.1 & 0.1 & 1.6 & 1.1 & 0 & 0.2 & 0.1 & 0.1 & 0.0 & 2.7 \\
\hline & & Min. & 18.5 & 5.7 & 2.4 & 2.5 & 1.6 & 6.1 & 1.8 & 2.5 & 1.4 & 0.9 & 13.3 & 9.6 & 5.3 & & 0.5 & 0.7 & 0.4 & 30.7 \\
\hline & & Max. & 23.0 & 7.3 & 3.1 & 3.0 & 2.0 & 8.1 & 2.2 & 3.3 & 1.8 & 1.3 & 18.6 & 13.1 & 7.1 & 2.8 & 0.7 & 1.2 & 0.5 & 39.0 \\
\hline & Females & & & & & & & & & & & & & & & & & & & \\
\hline 19 & DTU 303 & - & 24.2 & 7.1 & 3.1 & 2.9 & 1.9 & 7.3 & 2.1 & 3.3 & 1.7 & 1.1 & 16.7 & 12.0 & 6.6 & 2.6 & 0.7 & 0.7 & 0.6 & 36.7 \\
\hline 20 & DTU 304 & - & 25.5 & 7.3 & 3.2 & 2.9 & 2.1 & 8.0 & 2.0 & 3.2 & 1.8 & 1.2 & 17.3 & 12.8 & 6.7 & 2.5 & 0.7 & 0.8 & 0.6 & 38.7 \\
\hline \multirow[t]{5}{*}{21} & DTU 305 & - & 25.9 & 7.0 & 2.9 & 3.0 & 2.7 & 7.5 & 2.3 & 3.3 & 1.8 & 1.2 & 16.1 & 11.9 & 6.2 & 2.4 & 0.7 & 0.7 & 0.6 & 35.6 \\
\hline & & Mean & 25.2 & 7.1 & 3.1 & 2.9 & 2.2 & 7.6 & 2.1 & 3.3 & 1.8 & 1.2 & 16.7 & 12.3 & 6.5 & 2.5 & 0.7 & 0.7 & 0.6 & 37.0 \\
\hline & & SD & 0.9 & 0.2 & 0.2 & 0.1 & 0.4 & 0.4 & 0.1 & 0.0 & 0.1 & 0.1 & 0.6 & 0.5 & 0.3 & 0.1 & 0.0 & 0.1 & 0.0 & 1.6 \\
\hline & & Min. & 24.2 & 7.0 & 2.9 & 2.9 & 1.9 & 7.3 & 2.0 & 3.2 & 1.7 & 1.1 & 16.1 & 11.9 & 6.2 & 2.4 & 0.7 & 0.7 & 0.6 & 35.6 \\
\hline & & Max. & 25.9 & 7.3 & 3.2 & 3.0 & 2.7 & 8.0 & 2.3 & 3.3 & 1.8 & 1.2 & 17.3 & 12.8 & 6.7 & 2.6 & 0.7 & 0.8 & 0.6 & 38.7 \\
\hline
\end{tabular}




\begin{tabular}{|c|c|c|c|c|c|c|c|}
\hline № & Specimen ID & $\begin{array}{c}\text { Type } \\
\text { status }\end{array}$ & TL & FL & IMTL & 1TOEL & 4TDD \\
\hline & Males & & & & & & \\
\hline 1 & ZMMU A5934 & holotype & 11.7 & 12.3 & 0.7 & 2.0 & 0.7 \\
\hline 2 & ZMMU A5935 & paratype & 9.9 & 9.0 & 0.7 & 1.8 & 0.5 \\
\hline 3 & ZMMU A5936 & paratype & 9.3 & 9.1 & 0.6 & 1.7 & 0.4 \\
\hline 4 & ZMMU A5937 & paratype & 10.7 & 10.8 & 0.6 & 2.1 & 0.4 \\
\hline 5 & ZMMU A5938 & paratype & 11.3 & 11.2 & 0.5 & 2.1 & 0.4 \\
\hline 6 & ZMMU A5939 & paratype & 10.7 & 11.2 & 0.6 & 2.2 & 0.5 \\
\hline 7 & SYS a007400 & paratype & 10.9 & 10.8 & 0.7 & 1.9 & 0.5 \\
\hline 8 & ZMMU A5940 & paratype & 11.1 & 10.9 & 0.6 & 1.8 & 0.4 \\
\hline 9 & ZMMU A5941 & paratype & 11.2 & 11.0 & 0.7 & 2.0 & 0.5 \\
\hline 10 & ZMMU A5942 & paratype & 11.3 & 12.0 & 0.6 & 2.1 & 0.5 \\
\hline 11 & ZMMU A5943 & paratype & 11.9 & 12.0 & 0.7 & 2.5 & 0.7 \\
\hline 12 & ZMMU A5944 & paratype & 11.6 & 11.6 & 0.7 & 2.2 & 0.5 \\
\hline 13 & ZMMU A5945 & paratype & 12.0 & 12.1 & 0.6 & 2.1 & 0.5 \\
\hline 14 & ZMMU A5946 & paratype & 11.9 & 11.3 & 0.6 & 1.9 & 0.5 \\
\hline 15 & ZMMU A5947 & paratype & 12.2 & 12.2 & 0.8 & 2.3 & 0.4 \\
\hline 16 & ZMMU A5948 & paratype & 12.2 & 12.4 & 0.7 & 2.3 & 0.5 \\
\hline 17 & DTU 301 & - & 9.8 & 14.1 & 0.8 & 2.0 & 0.6 \\
\hline \multirow[t]{6}{*}{18} & DTU 302 & - & 9.6 & 13.5 & 0.9 & 1.9 & 0.6 \\
\hline & & Mean & 11.1 & 11.5 & 0.7 & 2.0 & 0.5 \\
\hline & & SD & 0.9 & 1.3 & 0.1 & 0.2 & 0.1 \\
\hline & & Min. & 9.3 & 9.0 & 0.5 & 1.7 & 0.4 \\
\hline & & Max. & 12.2 & 14.1 & 0.9 & 2.5 & 0.7 \\
\hline & Females & & & & & & \\
\hline 19 & DTU 303 & - & 11.5 & 17.2 & 1.0 & 2.2 & 0.6 \\
\hline 20 & DTU 304 & - & 12.3 & 18.4 & 1.1 & 2.4 & 0.8 \\
\hline \multirow[t]{5}{*}{21} & DTU 305 & - & 10.0 & 15.8 & 1.1 & 2.2 & 0.9 \\
\hline & & Mean & 11.3 & 17.1 & 1.1 & 2.3 & 0.8 \\
\hline & & SD & 1.1 & 1.3 & 0.1 & 0.1 & 0.2 \\
\hline & & Min. & 10.0 & 15.8 & 1.0 & 2.2 & 0.6 \\
\hline & & Max. & 12.3 & 18.4 & 1.1 & 2.4 & 0.9 \\
\hline
\end{tabular}

3 


\section{Figure 1}

Distribution of the genus Micryletta and the new species.

(A) Map of Southeast Asia with approximate range of the genus Micryletta shown in red.

Black circles indicate type localities of the currently recognized taxa within Micryletta. Yellow stars show distribution of Micryletta nigromaculata sp. nov., black dot in the center of icon indicates the type locality (Cat Ba Island). Black square indicates the inset shown in detail in B. (B) Map of northern Vietnam, showing distribution of Micryletta nigromaculata sp. nov. and the Red River basin; 1 - Cat Ba National Park, Hai Phong Province (type locality); 2 - Cuc Phuong National Park, Ninh Binh Province. Photo by Nikolay A. Poyarkov.

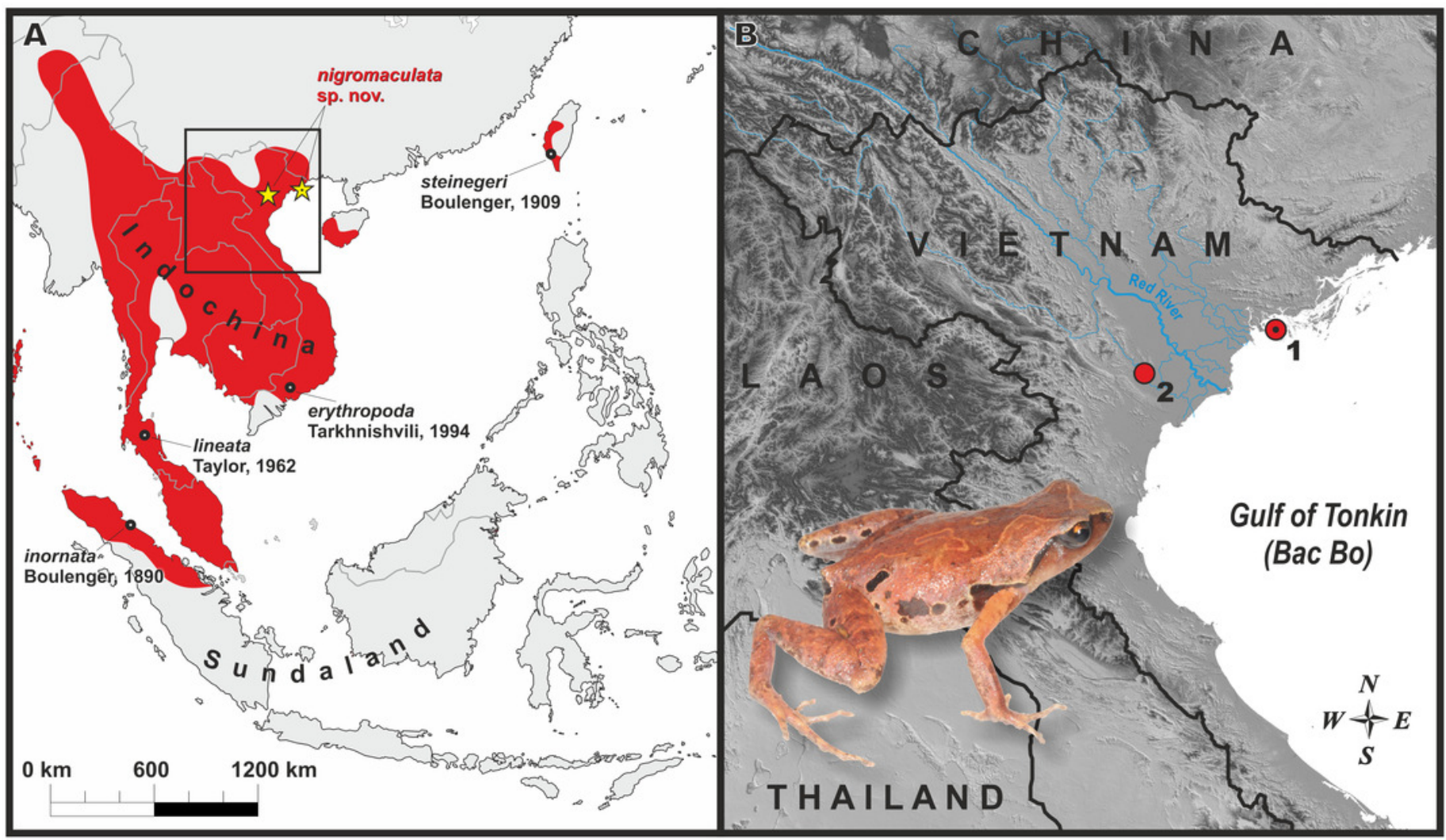


Figure 2

Phylogenetic BI tree of Micryletta reconstructed on the base of $947 \mathrm{bp}$ of $16 \mathrm{~S}$ rRNA gene.

Values on the branches correspond to BI PP/ML BS, respectively. For specimen, locality and GenBank Accession Number information see Table 1. Photos by Nikolay A. Poyarkov (Micryletta nigromaculata sp. nov., M. erythropoda, M. cf. inornata) and Chung-Wei You (M. steinegeri).

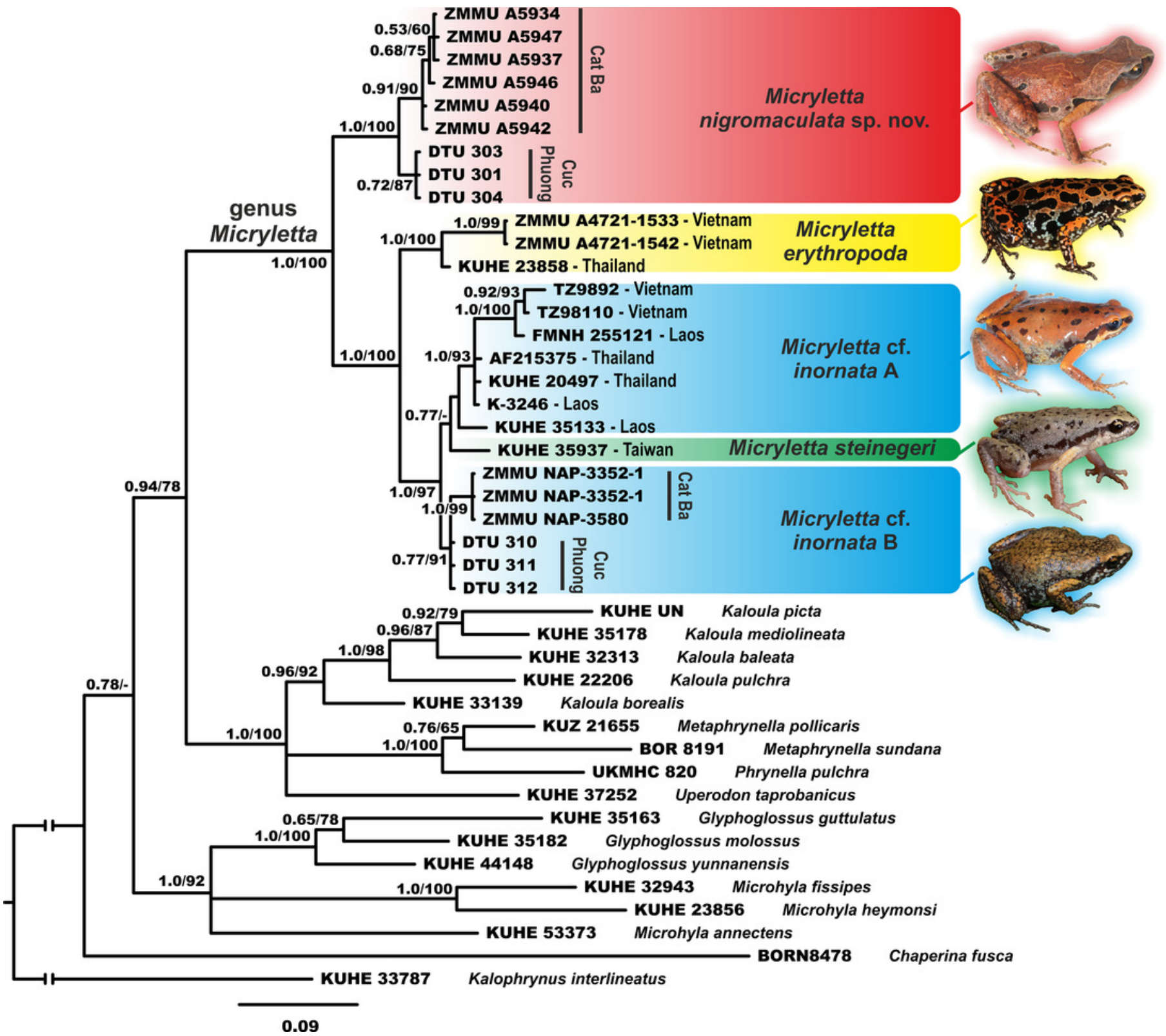




\section{Figure 3}

Holotype of Micryletta nigromaculata sp. nov. (ZMMU A5934), male, in life.

(A) Dorsal view; (B) ventral view; (C) lateral view of head; (D) volar view of left hand; (E) plantar view of right foot. Photos by Nikolay A. Poyarkov.

*Note: Auto Gamma Correction was used for the image. This only affects the reviewing manuscript. See original source image if needed for review. 


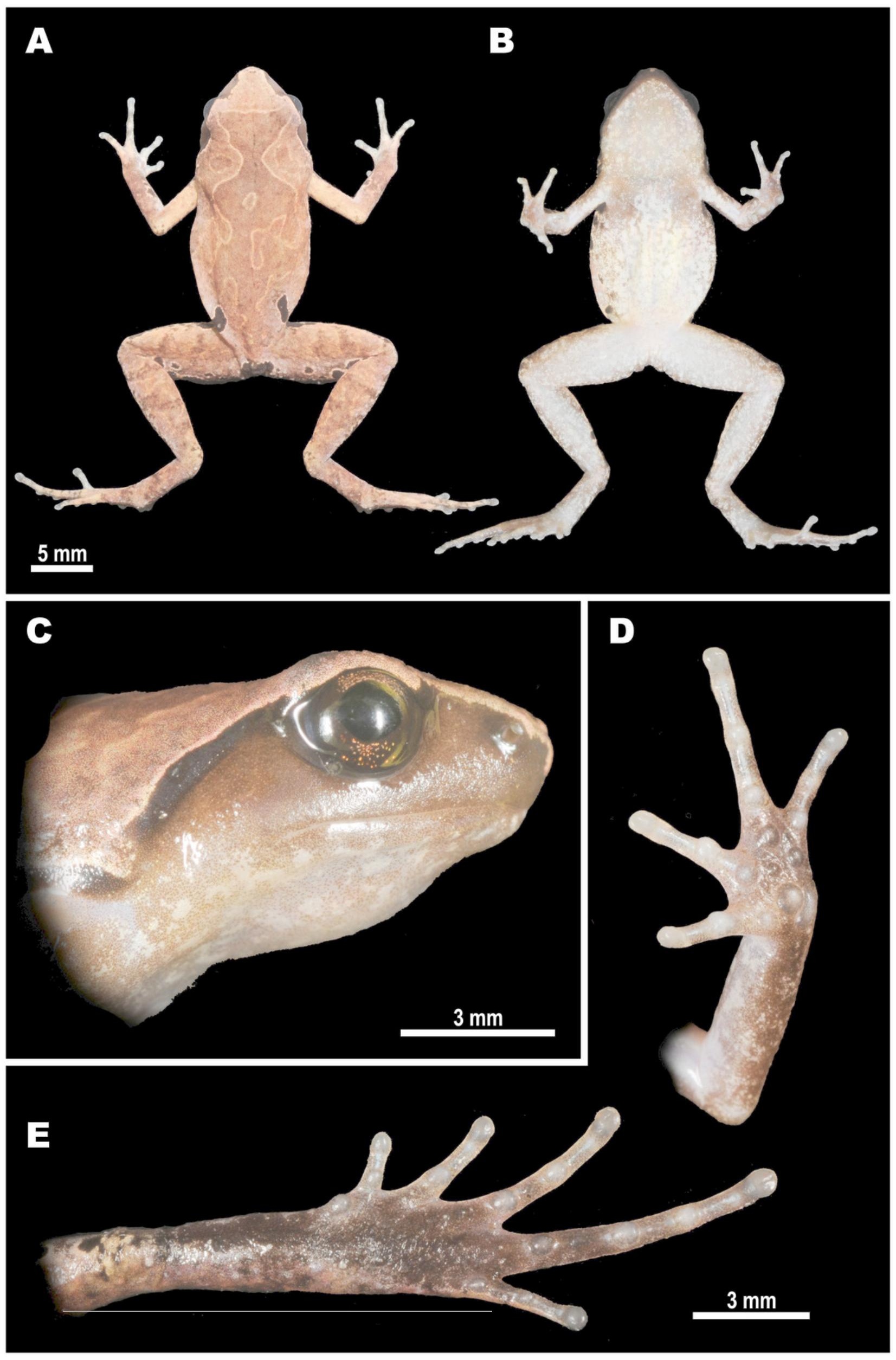




\section{Figure 4}

Holotype of Micryletta nigromaculata sp. nov. (ZMMU A5934), male, in situ in dorsolateral view.

Photo by Nikolay A. Poyarkov.

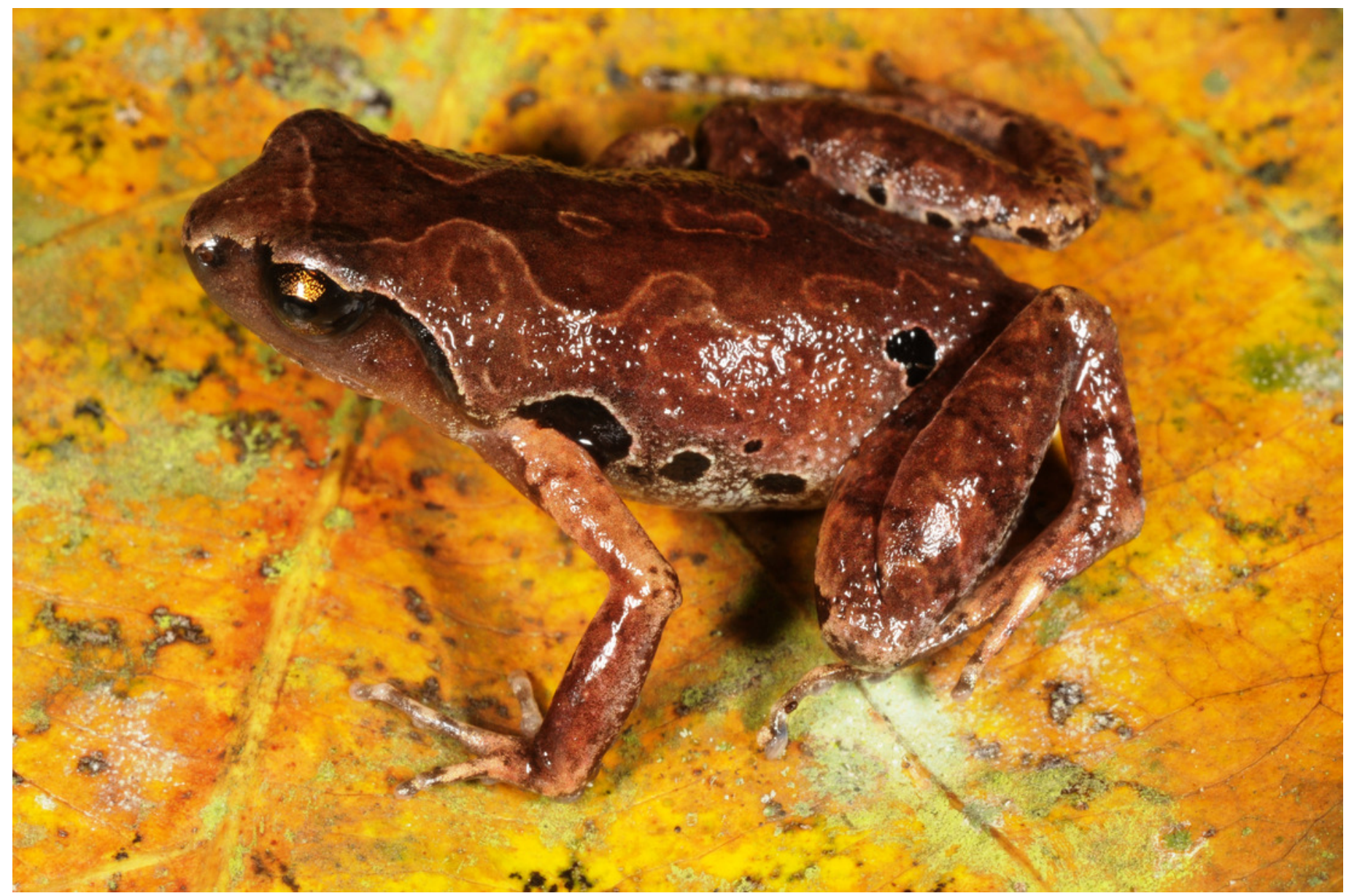




\section{Figure 5}

Morphological details of the male paratype of Micryletta nigromaculata sp. nov. (ZMMU A5945) in preservative.

(A) volar view of the right hand; (B) plantar view of the right foot. Scale bar equals $3 \mathrm{~mm}$. Drawings by Valentina D. Kretova. 

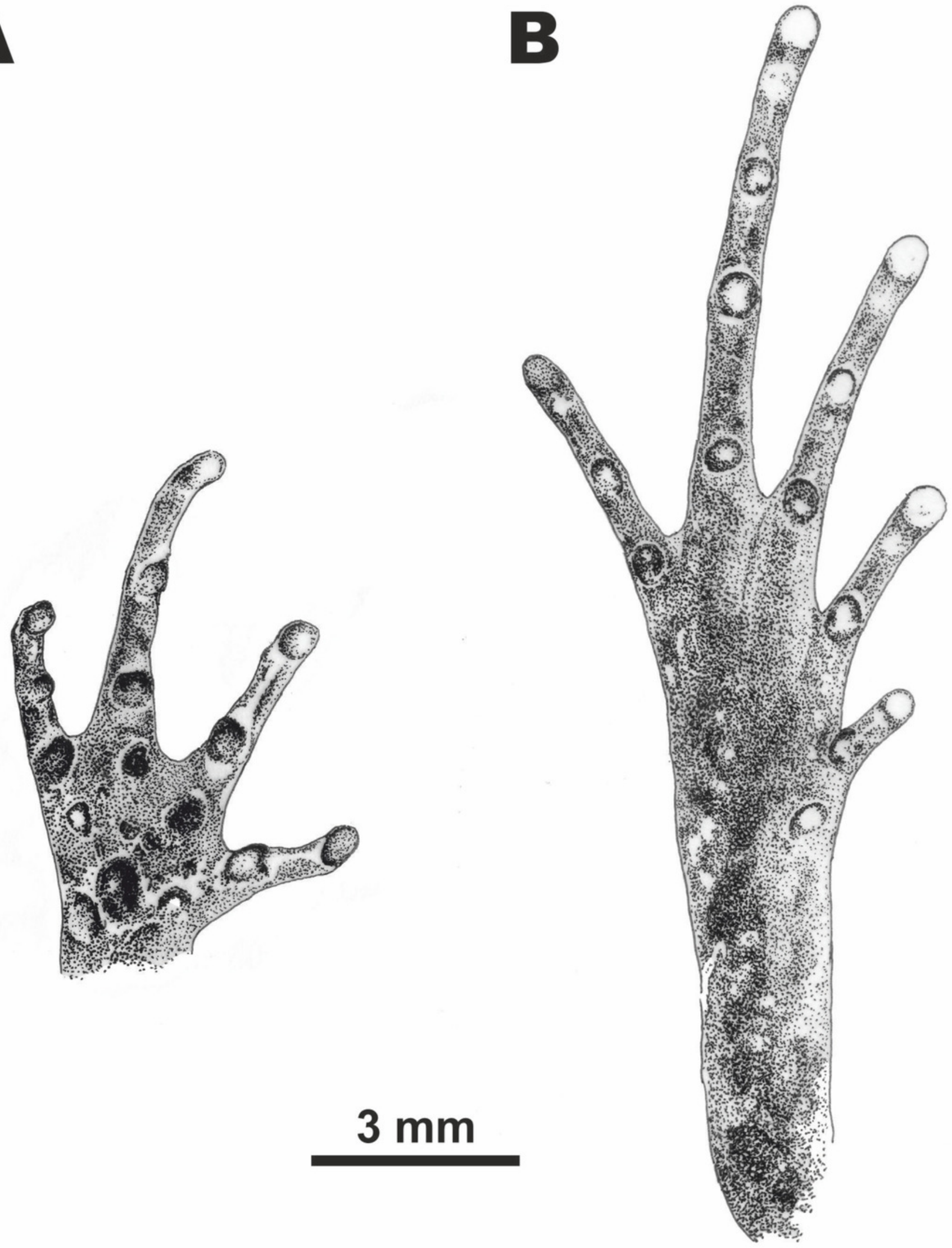
Figure 6

Color variation of Micryletta nigromaculata sp. nov. in life.

Cat Ba National Park: (A) Male paratype ZMMU A5945; (B) male paratype ZMMU A5935 in situ; Cuc Phuong National Park: (C) male DTU 302 in situ; (D) female DTU 303 in situ. Photos A-B by Nikolay A. Poyarkov; C-D by Tan Van Nguyen.
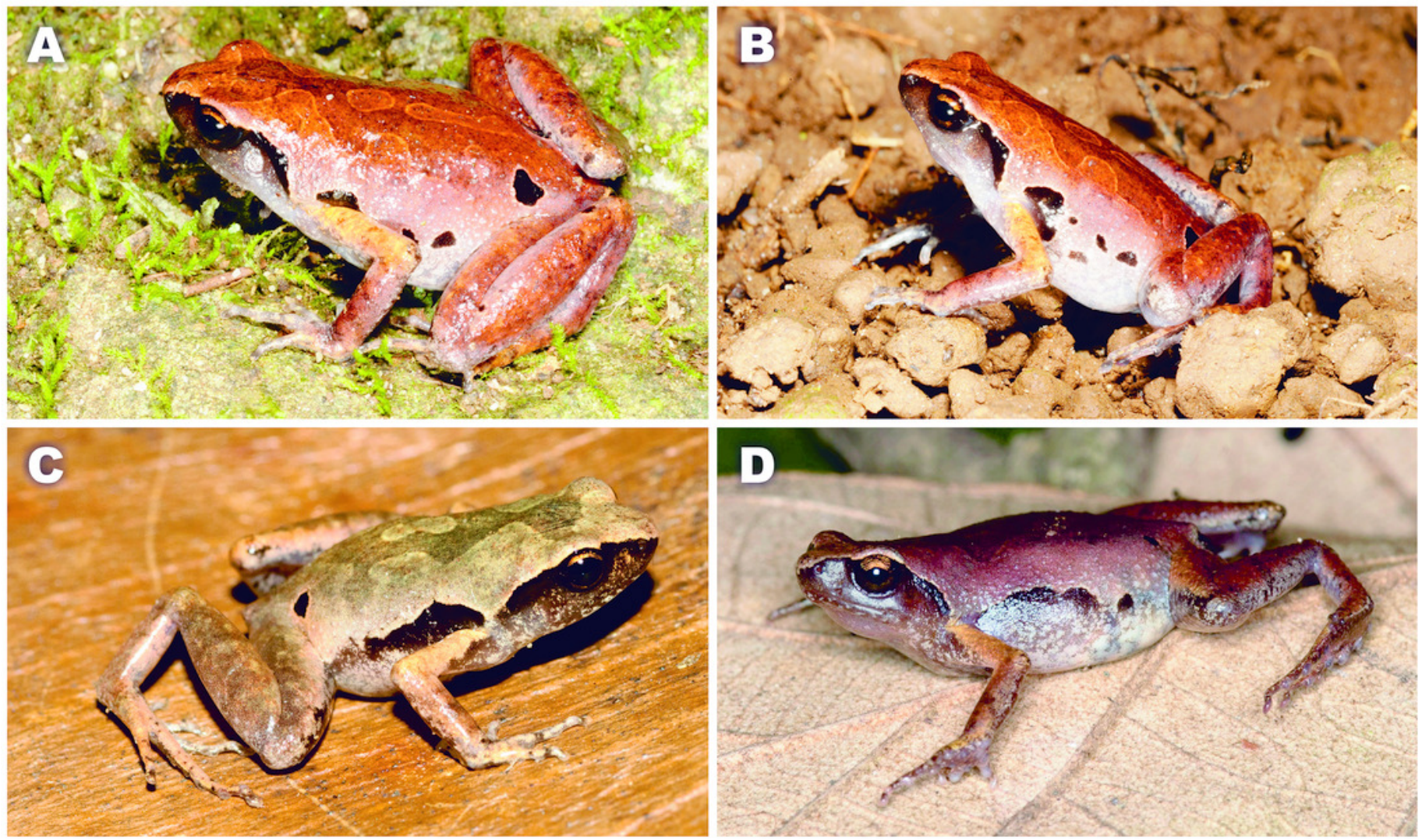